\title{
Processing unambiguous verbal passives in German ${ }^{1}$ NINO GRILLO
}

\author{
Department of Language and Linguistic Science, University of York
}

\author{
ARTEMIS ALEXIADOU \\ Institut für Anglistik und Amerikanistik, Humboldt-Universität zu Berlin \& \\ Leibniz-Center General Linguistics (ZAS) \\ BERIT GEHRKE \\ Institut für Slawistik und Hungarologie, Humboldt Universität zи Berlin \\ NILS HIRSCH \\ Institut für Anglistik und Amerikanistik, Humboldt Universität zu Berlin \\ CATERINA PAOLAZZI \\ Department of Linguistics, University College London
}

\author{
ANDREA SANTI \\ Department of Linguistics, University College London
}

(Received 1 November 2016; revised 19 July 2018)

\begin{abstract}
Passivization played a central role in shaping both linguistic theory and psycholinguistic approaches to sentence processing, language acquisition and impairment. We present the results of two experiments that simultaneously test online processing (self-paced reading) and offline comprehension (through comprehension questions) of passives in German while also manipulating the event structure of the predicates used. In contrast to English, German passives are unambiguously verbal, allowing for the study of passivization independent of a confound in the degree of interpretive ambiguity (verbal/adjectival). In English, this ambiguity interacts with event structure, with passives of stative predicates naturally receiving an adjectival interpretation. In a recent study, Paolazzi et al. (2015, 2016) showed that in contrast to the mainstream theoretical perspective, passive sentences are not inherently harder to process than actives. Complexity of passivization in English is tied to the aspectual class of the verbal predicate passivized: with eventive predicates,
\end{abstract}

[1] Acknowledgements: This research was funded by the DFG Leibniz Prize AL 554/8-1 to Artemis Alexiadou. We are also grateful to the audience of the workshop on The Syntax of Argument Structure at the 38th Annual DGfS Conference, Konstanz, and the anonymous reviewers for the Journal of Linguistics. 
passives are read faster (as hinted at in previous literature) and generate no comprehension difficulties (in contrast to previous findings with mixed predicates). Complexity effects with passivization, in turn, are only found with stative predicates. The asymmetry is claimed to stem from the temporary adjectival/verbal ambiguity of stative passives in English. We predict that the observed difficulty with English stative passives disappears in German, given that in this language the passive construction under investigation is unambiguously verbal. The results support this prediction: both offline and online there was no difficulty with passivization, under either eventive or stative predicates. In fact, passives and their rich morphology eased parsing across both types of predicates.

KEYWORDS: complexity, event structure, German, passives, sentence processing

\section{INTRODUCTION}

Passivization has played a key role in formulating theories of syntax and sentence processing. From early on in the generative grammar tradition, experimental work on passives has been used to evaluate theoretical proposals. Passive processing was used in testing the first psycholinguistic theory: the Derivational Theory of Complexity (DTC). The DTC emerged from transformational grammar and proposed that the overall complexity of a sentence increases with each application of a transformation; that is, the more transformational steps the higher the complexity. In directly testing the DTC, the time to read sentences that varied in the number of transformations (e.g. passives, negation, wh-questions) was measured. While there was some support for the DTC, it was abandoned as not all cases bore out the predicted differences. Nonetheless, much future work still considered that some transformations are difficult, including the movement required by passives. This can be observed across language processing fields. (i) Bever (1970) famously used passives to argue for heuristic strategies in parsing. The errors observed in comprehension were attributed to a heuristic of assigning the first NP to agent in English; (ii) Borer \& Wexler's (1987) maturation account builds on the delay in the acquisition of A-movement, as required by passives; (iii) Grodzinsky (1990) proposed that the failure to understand passives observed in people with agrammatic aphasia is better understood as part of an overarching problem with the representation of movement-derived sentences.

In a more recent influential paper on the processing of passives, Ferreira (2003) showed that unimpaired adult speakers appear to (somewhat) consistently fail to correctly assign thematic roles in passives, i.e. fail to understand who did what to whom in a passive sentence. This result, she argued, supports the idea that algorithmic processing is often replaced by PROCESSING HEURISTICS (Good Enough Processing; Christianson et al. 2001, Ferreira 2003, Ferreira \& Patson 2007, Ferreira \& Christianson 2016, Karimi \& Ferreira 2016). Building on Bever (1970) and Townsend \& Bever (2001), she argued that the first NP is attributed agenthood, resulting in an incorrect interpretation of the English passive. As the participants were not at floor levels on passives, she further assumed that computationally more taxing algorithmic processes often correct 
the heuristic, just not consistently. This strengthened one common belief about passives: they are harder to parse than actives. If this were not the case, the algorithmic processes would always succeed in correcting the heuristic, and performance on the passive should be equivalent to the active.

Consideration of additional previous 'online' processing studies, however, delivers a fragmented picture on this matter. While the already discussed offline data from adult processing (notably the study in Ferreira 2003, just mentioned) and most (early) research in both language acquisition (see e.g. Bever 1970, Horgan 1978, Maratsos et al. 1985, Borer \& Wexler 1987 a.o.) and language impairment (Grodzinsky 2000, Grillo 2008 a.o.) point to passives being more difficult than actives, online studies paint a different picture. Passives have repeatedly been reported to be read faster than actives (Carrithers 1989, Rohde 2003, Traxler et al. 2014), even if not significantly so in all cases. These results appear to suggest the unexpected conclusion that actives are harder to parse than passives, in sharp contrast to the offline results reported above.

To address this apparent paradox and to further understand the nature of (any) complexity of passivization, Paolazzi et al. $(2015,2016)$ identified a number of factors that could help to explain why passivization demonstrates divergent online and offline complexity effects. These include (1) aspectual class of the verbal predicates involved (stative versus eventive), which interacts with passivization for the availability of verbal/adjectival passive reading cross-linguistically and is known to affect passives processing in acquisition, and (2) morphological 'richness' of passives when compared with their active counterparts.

This paper will consider these two factors from a cross-linguistic perspective. To date, psycholinguistic studies of passivization have focused primarily on English. However, cross-linguistic variation in passivization can provide further insight into these issues. Specifically, we consider German, as it differs from English with respect to these two factors in informative ways.

In Section 2, we discuss these two factors, considering both prior English studies by Paolazzi et al. $(2015,2016)$ and how German can further inform these data. Sections 3 and 4 present two German experiments to test these two factors, adapted from the original English experiments in Paolazzi et al. (2015) and Paolazzi et al. (2016). The experiments simultaneously test online processing (using self-paced reading) and offline comprehension (through comprehension questions following each sentence) of passives. The results show a partial overlap with what was previously observed for English: passives are read just as fast (or faster) than actives at multiple regions also in German. However, contrary to what was observed for English by Paolazzi et al. (2016), we found that passives of stative predicates are understood just as well as their active counterparts. A final discussion, in Section 5, provides an account of this difference and explores potential avenues for future targeted cross-linguistic research. 


\section{TWO KEY FACTORS IN THE PROCESSING OF PASSIVES}

\subsection{Aspect and the disambiguation of adjectival/verbal passives in English}

English lacks a morphological distinction between adjectival and verbal passives, since both are introduced by a form of be, as illustrated in (1), which can be parsed either as an auxiliary (with verbal passives) or as a copula (with adjectival passives).

\section{(1) The boy was loved by everyone.}

Under common assumption, an adjectival passive is less complex than a verbal passive since it does not involve additional movement (in passivization) and therefore behaves just like an active construction in this respect. ${ }^{2}$ This simpler syntactic representation may lead to a preference of an adjectival parse. In particular, two main factors determine availability and strength of the ambiguity in English: first, the presence (and referential type) of a by-phrase; second, predicate semantics. Both are discussed in the following two sections.

\subsection{Passivization and the by-phrase}

Until recently, it was claimed for English that the presence of a by-phrase was enough to disambiguate towards the verbal reading, as by-phrases were assumed not to be available with adjectival passives. However, authors like McIntyre (2013) and Bruening (2014) have shown for English that by-phrases are also found with adjectival passives, and the literature on German adjectival passives (e.g. Rapp 1997, Kratzer 2000, Anagnostopoulou 2003, Maienborn 2007) has long acknowledged this fact (see also Alexiadou, Anagnostopoulou \& Schäfer 2015 for recent discussion of various languages). Thus, a sentence like (2) is still ambiguous between an adjectival reading (a sharp judgment on the poor quality of the lines in the drawing) and a verbal reading (a statement about a specific event of drawing involving an actual child).

(2) This picture is drawn by a child.

As Gehrke (2015) discussed at length, however, adjectival passives (at least of eventive predicates) are only compatible with by-phrases whose complement is weakly or non-referential (e.g. bare nouns and weak (in)definites, as in (2)) or

[2] In particular, it has been shown that the DP in subject position of adjectival passives behaves like an external argument (see McIntyre 2013 for recent discussion). Hence, under the common assumption that verbal passivization involves the movement of an internal argument DP, possibly over the external argument DP in the (silent or overt) by-phrase, this movement should not be assumed for adjectival passives. The same holds for the movement proposed in more recent approaches to verbal passivization under which a lower VP shell is moved, dragging along the internal argument (e.g. Collins 2005; Gehrke \& Grillo 2007, 2008). 
generic (as in (1)), but not with strongly referential ones (such as regular definites, specific indefinites, possessives, proper names); we will henceforth call the latter 'referential by-phrases'. This holds for English and German alike, as illustrated in (3) (see also discussion in Alexiadou, Gehrke \& Schäfer 2014).

(3) (a) The door seemed broken/opened/painted (*by Mary).

(McIntyre 2013)

(b) Der Mülleimer ist (*von meiner Nichte) geleert. the rubbish-bin is by my niece emptied Intended: 'The rubbish bin is emptied by my niece.'

(Rapp 1996)

A further difference between stative and eventive inputs to passivization in English can be observed when we turn to short passives, i.e. passives without by-phrases, which in prinicple can be verbal or adjectival. In particular, English short passives of eventive predicates freely support implicit external arguments, whereas those of stative predicates do not, given that the former allow control into a purpose clause (4a), whereas the latter do not (4b).

(4) (a) John was killed to collect the inheritance.

(b) *John was loved to collect the inheritance.

A similar contrast can be observed in the following examples.

(5) (a) Mary loved/worried John to push him to resign.

(b) *John was worried to push him to resign.

(c) John was attacked to push him to resign.

Short passives of stative predicates in English only allow implicit generic byphrases, as evidenced by the ability to support an ultimate cause/source of a particular state (his charisma), rather than a purpose clause.

(6) John was loved (by everyone) for his charisma.

Hence, in the presence of a referential by-phrase, an English passive is unambiguously verbal, since such a $b y$-phrase is not available for an adjectival passive in English.

Given these observations, let us consider the passive sentences in (7) (items 23 and 24 from Experiment 2 of Traxler et al. 2014), which Traxler et al. used to test whether passives are harder to process than actives.

(7) (a) The neighbours were upset by the college students living next door.

(b) The child was upset by the nurse at the clinic this morning.

One problem we see with (7) is that, at least early on in parsing (i.e. prior to encountering the referential by-phrase), it is not possible to infer that a verbal as opposed to adjectival passive needs to be built. Both sentences in (7a) and 
(7b) can receive a predicative, non-passive interpretation (i.e. an adjectival passive interpretation), as shown by the felicitous continuation with about in (8).

(8) The neighbours were upset about the noise.

This is a problem for online reading time (RT) studies, which seek to find complexity effects at the verb, as a verbal passive structure is not necessarily projected by this region. Traxler et al. (2014) also looked at RTs at the by-phrase. However, complexity effects are often found in spill-over regions in self-paced reading, so there is a possibility that such effects have been missed here, especially since the $b y$-phrases were typically short (at most two or three words, although the items in (7) are already improving on this point). As for offline studies, one might argue that this is not (necessarily) a problem, as by the end of the sentences in (7), the ambiguity is gone. However, the potential for two parses could generate some interference in memory, providing an explanation of the offline results in Ferreira (2003) on grounds independent of passivization itself.

An additional point, to which we turn now, is that the ambiguity between a verbal and an adjectival passive parse is particularly prominent with stative inputs, passives of which, we will argue below, are preferably parsed as adjectival. With stative inputs, then, it becomes impossible to separate complexity effects due to voice alternations from those due to reanalysis of an adjectival as a verbal passive upon encountering a referential by-phrase. Let us then turn to the nature of the particular aspectual class of verbs triggering verbal and adjectival passive interpretations.

\section{Passivization and verb type}

We conjecture that the problem of a passive construction being potentially ambiguous between a verbal and an adjectival passive is more prominent with certain verbal inputs. In particular, we take an adjectival passive to ascribe a temporal stative property to its subject, and therefore the best input is a verbal predicate containing a stative subevent, as already noted by Rapp (1997). More precisely, the state has to be interpretable as a temporal state, so that good inputs are some states and changes of state (i.e. accomplishments and achievements, in the sense of Vendler 1957), whereas activities/processes, such as kick, as well as more lasting states like know, are less good inputs (see also Alexiadou et al. 2015, Gehrke 2015 and literature cited therein). Hence, the English passive in (9) will always be parsed as a verbal passive, given that an adjectival interpretation (out of context and without additional coercion) is unavailable.

\section{(9) John was kicked.}

In some languages, also the verbal passive comes with aspectual input requirements, in the sense that at least for English (and also for Italian, but not for German, as we will discuss in more detail in 2.4), the best input to a verbal passive is an eventive predicate (i.e. activities, accomplishments, achievements). 
Passivized stative predicates, then, like the one in (10), will first and foremost be parsed as an adjectival passive, unless context (e.g. a referential by-phrase) requires a verbal passive interpretation; we will come back to this below.

John was loved.

Hence, the ambiguity between a verbal and an adjectival passive is eliminated, or at least rendered much less prominent, with some predicates: passives of activities are interpreted as verbal and passives of states are preferably interpreted as adjectival.

More generally, then, stative predicates very naturally occur in adjectival passives, while at the same time resisting verbal passivization in at least some languages, including English. As we will discuss in more detail in Section 2.4, this is even more clearly visible in Italian, where unambiguous verbal passivization with the auxiliary venire 'come' is restricted to predicates that involve a change of state. Thus, when applied to stative predicates such as love and worry, a verbal passive in these languages is strongly marked, and we assume that in this case such predicates undergo coercion into a consequent state subevent to receive an inchoative, i.e. eventive interpretation (for a more general discussion of this issue, see Gehrke \& Grillo 2007, 2009); this comes with a cost clearly observable in reduced acceptability. In the same Section 2.4, we will see that German, which unambiguously introduces adjectival and verbal passives through a formal distinction between the verbal auxiliary and the adjectival copula, differs from both English and Italian in allowing (some) states to appear in verbal passives and importantly in not forcing them into an inchoative reading.

The relevance of predicate semantics, as well as the adjectival/verbal ambiguity, in passivization is well known in the acquisition literature. Traditionally, a distinction is made between children's ability to comprehend and produce 'actional' passives, claimed to be available, and 'non-actional' passives, claimed to be problematic (see, e.g., Maratsos et al. 1985, Borer \& Wexler 1987, Fox $\&$ Grodzinsky 1998). In this account, children succeed in interpreting (short) actional passives because actional predicates easily derive an adjectival interpretation, which, unlike the verbal interpretation, is accessible to them (cf. the girl was well-combed). Passives of non-actional predicates, on the other hand, would not allow an adjectival-passive interpretation (cf. *the girl was well-feared) and can only be interpreted as verbal passives, which in this model cannot be derived by children.

More recently, Gehrke \& Grillo (2009) proposed that the relevant distinction might be better couched in the difference between eventive and stative predicates and in particular combined with the idea that verbal passivization requires an event structure with at least two subevents, which is absent in states. Stative predicates, then, they claimed, are harder to passivize because they involve inchoative coercion into a transition into state, which adds this additional subevent.

Aspectual coercion (e.g. Moens \& Steedman 1988, de Swart 1998), i.e. the reinterpretation of a given event of a particular event class as belonging to a 
different one (e.g. of a state as an inchoative state - an achievement, by adding an initial bound to the state, or of an achievement as an accomplishment, by adding a preparatory process), has been previously shown to increase processing complexity (Piñango, Zurif \& Jackendoff 1999, McElree et al. 2001, Traxler, Pickering \& McElree 2002, Piñango et al. 2006, Bott 2010, Paczynski, Jackendoff \& Kuperberg 2014). More crucially for the present discussion, Brennan \& Pylkkänen (2010) showed that inchoative coercion increases processing complexity, leading to longer RTs in sentences like (11b) than (11a).
(a) The boy was asleep.
(stative)
(b) Within 2 minutes, the boy was asleep.
'Within 2 minutes, the boy came to be asleep.'
(Coerced inchoative)

(Brennan \& Pylkkänen 2010: 781 ex. (1))

Data from aphasia and acquisition indirectly support the coercion account, showing a similar distinction to be at play, in the sense that both populations have been shown to have more problems in comprehending passives of stative than of eventive inputs. For discussion of results from aphasia, see Grodzinsky (1995) and Grillo (2008), and for additional empirical support of the event-structure based account of acquisition of passivization in Gehrke \& Grillo (2009), see Crawford (2012), Estrela (2014), Snyder \& Hyams (2015) and especially Volpato, Verin \& Cardinaletti (2015). ${ }^{3}$

Thus, while the distinction between stative and eventive inputs to passivization has thus far featured prominently in the acquisition literature, it seems to not have found its way into the adult processing literature. Since, as further argued here, event structure, and in particular the difference between states and events, is a factor affecting the adjectival/verbal passive disambiguation, Paolazzi et al. (2015, 2016) argued that previous offline and online results are potentially confounded. The problem with previous studies then is that sentences containing particular stative verbs, but also particular types of eventive verbs that readily derive adjectival passives, might be misconstrued as adjectival passives up until the head of a referential by-phrase is encountered, leading to reanalysis, which is usually costly. These costs should be observable in lower accuracy scores and/or longer RTs online. Very importantly, however, online costs should only be observed at or after the by-phrase, since at earlier regions (e.g. the verb, typically the region of interest in these earlier studies) the ambiguity still persists as an adjectival parse is not problematic. We will see in Section 2.3 that these predictions were supported by Paolazzi et al. $(2015,2016)$.

[3] Note that the similarity between Gehrke and Grillo's account and Borer and Wexler's account is only apparent. While there obviously is a partial overlap between actional/eventive and nonactional/stative predicates, the rationales of the two accounts are very different. For Borer and Wexler, what leads to better comprehension is the possibility to generate an alternative adjectival interpretation with actional predicates. For Gehrke and Grillo, passives of eventives are easier to parse - as verbal passives - because they do not require coercion. 
In comparison to actives, English passive sentences typically contain additional morphological cues such as the passive auxiliary and the preposition by, introducing the external argument. Paolazzi et al. $(2015,2016)$ suggested that previous literature overlooked the role that morphological information can play in modulating reading times. Specifically, the additional morphological cues in the passive may speed up processing at specific points for reasons that are independent of the more general question of the complexity of the passive voice itself. For instance, previous work on passivization has typically compared actives without auxiliaries (in simple tenses) with passives in which an auxiliary immediately precedes the verb, as in (12).

(a) The boy attacked the girl.

(b) The boy was attacked by the girl.

In comparison with the active, the passive version of the sentence contains these two additional elements (auxiliary, by), and this might facilitate incremental parsing by reducing uncertainty about the type of the following constituent. In a traditional bottom-up approach to sentence processing, processing of a word initiates when that word is encountered. This would suggest that any difference in RTs at the verb observed when studying contrasts such as the one in (12) should be attributed to the inherent complexity of processing the verb attack in the active and passive voices. Recent perspectives, however, have seen a revival of early analysis by synthesis accounts (Bever \& Poeppel 2010), which emphasize the importance of top-down, predictive processes in sentence processing. Several studies in experimental psycholinguistics have shown that processing complexity at particular regions in a sentence is modulated by expectations about coming words and constituent type for those regions. The contribution of these expectations to sentence processing has been formalized using the information theoretic notions of entropy and surprisal (Hale 2001).

Konieczny (2000) discussed the tension between principles of locality, which predict that complexity increases when increasing the distance between two dependent elements in a sentence (Gibson 1998), and antilocality effects issuing from anticipatory/predictive processes. Konieczny (2000) first observed that the addition of adjectival phrases to an object modifying relative clause led to faster RTs at the main verb in German. Since German is a language with (unmarked) subject-object-verb (SOV) order (in main clauses), addition of adjectives to a modified object means increasing the distance between the head of the object and the verb, yet RTs at the verb were found to be faster. Jaeger et al. (2008) found similar effects in English when more PPs were added to a center-embedded relative clause modifying the subject head of a main clause. One reasonable explanation for these effects is that the more the presentation of the verb (a required element in a subject-verb dependency) is delayed by presentation of modifiers, the higher the expectation of the parser for the next word to be the 
verb, i.e. the lower the level of surprisal of the parser in encountering the verb. More generally, structural analyses entertained for earlier regions of the sentence generate structural expectations about parts of the sentence that are yet to come (Lau et al. 2006, Staub \& Clifton Jr 2006, Staub, Clifton \& Frazier 2006, Levy et al. 2012, Traxler 2014). The amount of surprisal of a word/phrase in a syntactic environment relates to its predictability in that environment. ${ }^{4}$

In the case at hand, presence of the auxiliary might speed up RTs at the verb simply because it leads to an increased expectation that the following word will be a verb. In other words, since the likelihood for verbs to follow auxiliaries is very high, the computational load associated with processing verbs after auxiliaries is lower than when they are presented in isolation or following a noun.

Similarly, only in passives is the second DP the girl preceded by the preposition by, which again might well reduce its surprisal, as one immediately expects a noun phrase to follow the preposition, and this might lead to faster RTs within this region.

These kinds of expectation-based effects can thus be naturally captured within a surprisal account (Konieczny 2000, Hale 2001, Levy 2008 e.g.). More importantly, for the present discussion, this kind of effect should be controlled for whenever possible. While it is impossible to match the active and passive versions with respect to by, a proper comparison should control for the presence of the auxiliary, to avoid misinterpretation of RT effects due to reduced surprisal of a verb when preceded by an auxiliary with a genuine effect of voice alternation. As we will see, German naturally provides such a possibility across different types of predicates.

\subsection{Previous results in English}

Paolazzi et al. $(2015,2016)$ addressed these issues by simultaneously collecting comprehension accuracy and RT (self-paced) data while manipulating the predicate's event structure. In a first experiment (Paolazzi et al. 2015), only eventive predicates were used with a manipulation of voice (see (13a), (13b)); this move was intended to reduce to a minimum the chances that an adjectival passive parse would be projected. An additional condition with a progressive version of the active was used to control for effects of predictability at the verb following an auxiliary (13c). The stimuli were prenormed for plausibility of thematic role assignment to be equivalent across conditions.

[4] Importantly, surprisal is a local measure of transitional probability and should not be confused with global frequency of the syntactic construction as a whole. 'Under surprisal the difficulty of a word $w$ in a sentence is determined by the log of the inverse conditional probability of the context in which it appears $\log \frac{1}{P(w \mid \text { context })}$. Depending on how comprehenders formulate probabilistic expectations for upcoming events in a sentence, these conditional probabilities may reflect various structural features of the earlier part of the sentence.' (Levy et al. 2012: p. 15) 
(13) (a) The guitarist was rejected by the attractive and talented singer in the hall next to the pub.

(b) The guitarist rejected the attractive and talented singer in the hall next to the pub.

(c) The guitarist was rejecting the attractive and talented singer in the hall next to the pub.

All predicates used denoted complex events, specifically agentive/causative, eventive/resultative. Besides compatibility with progressive aspect, other standard diagnostics were employed to ensure a uniform set of eventive predicates. These included compatibility with adverbs of intent (deliberately), compatibility with in $x$ time modification, compatibility with a . . . and this event happened at 4pm scenario, and compatibility with VP-ellipsis (e.g. The guitarist rejected the singer and the doctor did so, too).

Importantly, there was no effect of voice on accuracy: passives were understood just as well as actives; in fact, accuracy scores were almost identical across conditions (passive $85.71 \%$; progressive $83.67 \%$; simple active $83.3 \%$ ). In addition, RTs at the verb did not differ in the auxiliary conditions (passive and progressive) but were significantly longer for simple actives without auxiliaries. This supports the idea that previously observed effects at this region (i.e. faster RTs for passives than actives) were due to the lack of auxiliary in the active condition. The results further showed faster RTs at multiple regions within the second DP (the attractive and talented singer) in passives; this effect reached significance at two regions (at the determiner and the conjunction). The authors ascribed this to the fact that the second DP is more predictable in passives than in actives because it follows the preposition by.

The results of this first experiment support the idea that previously observed faster RTs in passives can be accounted for within a surprisal account (Hale 2001). The richer morphology of English passives (auxiliary, by) when compared with the active can generate stronger predictions for upcoming syntactic constituents, significantly reducing the time needed to process them. That this account is on the right track is strongly supported by the observation that RTs at the verb are also faster for the progressive form than the simple active form (and do not differ between the progressive and the passive). Clearly, the presence of an auxiliary acts as a strong predictor for the following predicate, making it easier to process.

Lack of differences in accuracy when only eventive predicates are used provides preliminary support for the idea that previous results might have been confounded by the use of a mixed bag of predicates, with passives of stative predicates negatively affecting comprehension because they allow for adjectival interpretation at initial stages of parsing. In a second experiment, Paolazzi et al. (2016) addressed this issue by replacing eventive verbs with stative verbs, 
in particular subject experiencer verbs such as love, admire. ${ }^{5}$ Only two conditions were tested in this second experiment (simple active and passive), because stative predicates do not generally allow the progressive form for independent reasons. Besides the change in verb type, the only other modification with respect to the first study involved replacing the locative PPs (incompatible with statives) with implicit causality clauses. Once more, plausibility of thematic role assignment was controlled for in an online questionnaire. As in the previous study, comprehension questions followed each sentence to allow comparison of online and offline effects.

(14) (a) The guitarist was admired by the attractive and talented singer for keeping the band focused through the whole tour.

(b) The guitarist admired the attractive and talented singer for keeping the band focused through the whole tour.

As in the first experiment, faster RTs were found in passives at the verb and within the initial regions of the second DP. The effect, however, was reversed (at least numerically) at the head of the second DP (head of by-phrase). Crucially, with stative predicates, voice did affect accuracy, as participants understood actives better than passives (passive $78.3 \%$; active $86.1 \%, p=.003$ ). This was despite the fact that the presence of the auxiliary and the by facilitated initial stages of parsing.

Summarizing, passivization leads to faster RTs online, independently of predicate type, and this is consistent with a surprisal-based or expectation-based account. However, offline, passivization does seem to interact with the predicate type. More specifically, passivization of a stative predicate creates more difficulty than passivization of an eventive predicate. Paolazzi et al. argued that the results are compatible with an account under which participants initially assign an adjectival parse to the stative passive. As the participants continue to read, and specifically when the head of the referential by-phrase is encountered, it becomes clear that this analysis is untenable. ${ }^{6}$ Reanalysis and/or coercion is required, which explains numerically longer RTs at the head of the $b y$-phrase for passives and the offline comprehension difficulties. Taken together, these results support the claim that previous complexity effects with passives might in fact be due to the use of stative predicates alongside eventive ones.

A picture thus emerges in which passives indeed appear not to be more complex than actives by default, but only when formed on stative predicates and in virtue of

[5] The same diagnostics as those used for the first experiment were also used here, obviously with opposite predictions/selection criteria, e.g. incompatibility with progressive, incompatibility with in $x$ hours/compatibility with for $x$ hours, etc. Notice that (at least some of) the predicates selected can be coerced into an eventive reading by using these incompatible modifiers.

[6] Interestingly, RTs were numerically faster in actives than passives at this region, inverting the effect at previous regions, although this difference was only marginally significant $(p-$ value $=.08$ ). 
these leading to a temporary ambiguity between an adjectival and a verbal reading of the passive. The faster RTs, on the other hand, should not be taken as evidence that passives are easier to parse than actives, but rather that levels of surprisal might be lower at specific points during the processing of passives thanks to their richer morphology.

The broader significance of these results lies in shifting the attention to the complex interplay of event structure, the adjectival/verbal disambiguation, coercion and morphological richness. Given the complexity of the matter, this seems like a more promising route than treating each outcome of passivization as a monolithic phenomenon. Ideally, the contribution of each ingredient to processing complexity should be tested in isolation. It is immediately clear, however, that only a targeted and controlled examination of passive processing across languages might allow us to progress in this direction. Investigation of English alone can only take us so far, as many of these ingredients co-vary in a single language and are impossible to disentangle.

Here, the goal is to initiate this targeted cross-linguistic examination by considering the case of German, which will allow us to dig deeper into the contribution of the temporary adjectival/verbal ambiguity and morphology to the overall complexity of passives of stative predicates.

\subsection{Interpreting unambiguous verbal passives in German}

As discussed above, testing of voice alternations in English always involves having to deal with the ambiguity between adjectival and verbal readings of the passive. Judging from the results in Paolazzi et al. $(2015,2016)$, this ambiguity acts as a powerful confound. To a certain extent, this makes it harder to establish whether previous studies found passives to be more difficult to interpret than actives due to this ambiguity that arose from using a mixed bag of predicates or due to passivization itself. In this paper, we directly address this issue by testing German, a language that notably displays unambiguous verbal and adjectival passives. In particular, German verbal passives select the auxiliary werden 'become' (15a), while adjectival passives select the copula sein 'be' (15b).

(a) Der Gitarrist wurde zurückgewiesen. (verbal) the guitarist became rejected

'The guitarist was/has been rejected.'

(b) Die Reifen waren aufgepumpt.

(adjectival)

the tires were up-pumped

'The tires were inflated.'

This feature allows separation of potential effects of the verbal/adjectival ambiguity from effects solely due to the manipulation of voice. In particular, contrary to English, if an effect of complexity were to be detected, it would only be imputable to passivization. If the interpretation difficulties observed in English 
are due to the temporary ambiguity that arises from the stative predicates and not to passivization itself, we do not expect to observe any effects of voice on accuracy in German.

Another important characteristic of German verbal passives with werden is that, contrary to Italian venire passives, they do not force an eventive reading when embedding a stative verb (see Koo 1997: p. 98f). As we have briefly mentioned in Section 2.2, stative verbs, which are always good inputs to Italian essere-passives (16a), have to be coerced into an inchoative reading in Italian venire passives (16b). Furthermore, coercion is not always an option, as some predicates resist inchoative readings (16c) and generate ungrammatical sentences under venire.

(16) (a) Gianni è temuto/apprezzato dai suoi concittadini.

Gianni is feared/appreciated by.the his fellow-citizens

'Gianni is feared/appreciated by his fellow-citizens.'

(b) Gianni viene temuto/apprezzato dai suoi concittadini.

Gianni comes feared/appreciated by his fellow-citizens

'Gianni gets feared/appreciated by his fellow-citizens.'

(c) *Gianni viene preoccupato/appassionato dalla politica.

Gianni comes worried/excited by.the politics

Intended: 'Gianni gets worried/excited by politics.'

(Belletti \& Rizzi 1988: 311, (53/55))

(16a) is ambiguous between a verbal reading (inchoative) and an adjectival reading (the preferred reading), attributing a certain disfavor/popularity among his fellow-citizens to Gianni. (16b) can only receive an inchoative interpretation, i.e. it can only be interpreted as a state coming into existence: 'Gianni gets feared/appreciated at a given point', e.g. for something he did. The verbs in (16c), finally, resist the inchoative interpretation forced by venire, which explains their unacceptability in this environment.

German werden, on the other hand, does not force an inchoative interpretation of states, as shown in (17).

$$
\begin{aligned}
& \text { Hans wird von seinen Mitbürgern gefürchtet/geschätzt. } \\
& \text { Hans becomes by his fellow-citizens feared/appreciated } \\
& \text { 'Hans is (being) feared/appreciated by his fellow-citizens.' }
\end{aligned}
$$

Example (17), despite being a verbal passive, is only interpreted as attributing the property of being feared or appreciated to Hans. Importantly, the corresponding adjectival passive (with the copula sein 'be') in this case would be ungrammatical in German, but becomes more acceptable with additional modification by bei/von allen 'at/by all' or weltweit 'worldwide' (recall our discussion in $\$ 2.1$; see also Zifonun 1992, Zifonun, Hoffmann \& Strecker 1997 for earlier discussions of this point). This difference between German and Italian is likely to be attributed to the fact that Italian venire is a marked form, the Italian default auxiliary for passivization being essere 'be', which can introduce both adjectival (in its copular 
interpretation) and verbal passives. In German, on the other hand, werden is a fully grammaticalized default auxiliary used for verbal passives (see Eroms 1992). The exact characterization of this asymmetry is beyond the scope of this paper. The crucial issue for us here is that even if werden-passives are unambiguously verbal, they do not require an inchoative interpretation of states (see Rapp 1997: p. 124).

These characteristics make German an ideal testing ground for voice alternations, and, contingently, for the account proposed in Paolazzi et al. (2015, 2016).

\subsection{Parsing unambiguous verbal passives in German}

As we have seen, there is a partial overlap between English and German passives, leading to the expectation that similar parsing effects should be observed in the two languages. If the surprisal account of faster RTs in English passives is on the right track, we expect to find a similar effect of morphological richness on RTs in German. Surprisal should be reduced in regions following the preposition von 'by', and therefore also RTs in the passive should be reduced when compared with the active.

The same surprisal account, however, would make different predictions in the two languages in other regions. Faster RTs at the verb in English passives, for example, were shown to depend on the presence of the auxiliary. If passives are contrasted with progressives, in which the active verb is also preceded by an auxiliary, the effect is cancelled.

We argue that German might display shorter RTs in passives at the verb independently of the presence of an auxiliary. German actives and passives both have an auxiliary when verb-final sentences are compared across active and passive voices. However, the German passive, like the English passive, is still morphologically richer than the German active, since it has the additional von 'by'.

Importantly, in German canonical SOV orders, the by-phrase immediately precedes the main verb, as illustrated in (18).

Peter wurde in der Küche von Anna geschlagen.
Peter.NOM became in the kitchen by Anna hit

'Peter was hit in the kitchen by Anna.'

Hence, German provides a purer measure of the morphological effect independent of interactions with other factors potentially affecting complexity, such as integrating the argument with the verb and expectations for argument/adjuncts following predicates with particular event structure in the passive voice. Finally, since the verb is more likely to immediately follow a by-phrase than a direct object, surprisal at the verb might be smaller in passives than actives.

German word order is highly flexible compared with English, and a lot of variation can be found in the ordering of arguments and adjuncts. However, deviations from a basic 'canonical' order are generally considered to be informationstructurally marked and less acceptable out of the blue. Importantly, the canonical word order varies with voice. 
Crucially for us, the object DP in an active sentence can naturally be followed by additional event modifiers. In fact, this is the most natural word order out of the blue (i.e. as an answer to the question 'What happened?'), as the contrast in (19a), (19b) shows. With passives, however, the presence of additional modifiers intervening between the by-phrase and the verb would have to be licensed by a particular information structure (cf. (19c), (19d)).

(19) Was ist passiert? 'What happened?'

(a) Anna hat Peter in der Küche geschlagen.

Anna.NOM has Peter.ACC in the kitchen hit

'Anna hit Peter in the kitchen.'

(b) (?)Anna hat in der Küche Peter geschlagen.

Anna.NOM has in the kitchen Peter.ACC hit

'Anna hit Peter in the kitchen.'

(c) Peter wurde in der Küche von Anna geschlagen.

Peter.NOM became in the kitchen by Anna hit

'Peter was hit in the kitchen by Anna.'

(d) \#Peter wurde von Anna in der Küche geschlagen.

Peter.NOM became by Anna in the kitchen hit

'Peter was hit by Anna in the kitchen.'

Therefore, the difference in canonical word order in actives and passives suggests that prediction of a verb should be stronger after a by-phrase than after an accusative marked DP, leading to shorter RTs at the verb in passives than actives also in German.

In the following sections, we present the results of two self-paced reading experiments crossing event structure and voice in German, designed to test the processing of passivization in the absence of adjectival/verbal ambiguity and coercion. Indirectly, the experiments also test whether previously observed complexity effects in the processing of passives in English stem from the verbal/adjectival ambiguity and its interaction with event structure. If the original approach of Paolazzi et al., and our present reasoning, are on the right track, we can expect two types of results.

On the one hand, since both English and German passives display richer morphology than their active counterparts, we should be able to replicate the English online results, i.e. we should find faster RTs for passives in German, at least in the region of the $b y$-phrase. Since the $b y$-phrase precedes any information about event structure, this should be true of both eventive and stative predicates.

On the other hand, if the interaction of event structure and voice observed in accuracy in English is indeed caused by the verbal-adjectival ambiguity and/or the need to coerce states into an inchoative interpretation in English verbal passives, the lack of ambiguity of German verbal passives should cancel the effect of event structure observed in English, i.e. we should expect no difference in accuracy across both eventive and stative actives/passives. 


\section{EXPERIMENT 1}

\section{Participants}

Forty native German speakers from the University of Stuttgart participated in the experiment. All participants gave their informed consent and received either course credits or monetary compensation for their participation.

\section{Materials}

The original stimuli from Paolazzi et al. (2015), which contrasted active and passive sentences with eventive inputs, were carefully translated into German unambiguously verbal passives with the auxiliary werden 'become' and additionally adapted to German syntax. To ensure that the verb appeared in the same position in both the active and the passive versions, and that an auxiliary was present in both conditions, we compared past tense passives with active perfects (20).

(20) Example sentences from Experiment 1

(a) Der Gitarrist wurde von der attraktiven und talentierten the.NOM guitarist.NOM became by the attractive and talented Sängerin in der Konzerthalle zurückgewiesen, während es zu singer in the concert.hall rejected while it to regnen begann.

rain began

'The guitarist was (being) rejected by the attractive and talented singer in the concert hall as it began to rain.'

(b) Der Gitarrist hat die attraktive und talentierte Sängerin the.NOM guitarist.NOM has the attractive and talented singer in der Konzerthalle zurückgewiesen, während es zu regnen in the concert.hall rejected while it to rain begann. began

'The guitarist had rejected the attractive and talented singer in the concert hall as it began to rain.'

All items had the same structure as in (20), with a subject DP followed by the auxiliary (either become or have), the by preposition (in the passive condition only), the second DP (with a definite determiner followed by two conjoined adjectives and the $\mathrm{N}$ ), a locative preposition, the participle and finally a temporal subordinate clause (see Appendix A for a full list of stimuli). A long second DP was used to replicate the results in Paolazzi et al. (2015), which found faster RTs at multiple regions within the second DP. Number of words was matched 
across conditions; one extra word was inevitably present in the passive (by) when compared with the simple active condition. ${ }^{7}$

Contrary to the experiment in Paolazzi et al. (2015), the present experiment only contrasted two conditions. The progressive condition was excluded from the experiment for the following reason. German lacks a progressive, so we had to rely on a different periphrastic verb form: the perfect (which, unlike the English perfect, most often functions like a simple past). Therefore, the active version already contained an auxiliary (the perfect auxiliary), which ensured proper comparability with passives along this dimension.

Thirty items per condition were constructed, manipulating Voice [active versus passive] with an additional 60 fillers. To ensure that participants paid due attention to the task, a comprehension question followed each stimulus sentence. Half of the questions required 'Yes' responses and the other half required 'No' responses (e.g. Hat der Gitarrist die Sängerin zurückgewiesen? 'Did the guitarist reject the singer?'). The questions exclusively targeted thematic relations between different arguments of the verb. ${ }^{8}$ All nouns and verbs in the questions had been used in the actual sentences.

\section{Procedure}

The experiment was conducted in a word-by-word self-paced reading fashion with a moving window display paradigm (Just, Carpenter \& Woolley 1982). A Latin-square design was used, to ensure that each subject would see only one instance of each sentence (i.e. either the active or the passive version). The experiment was run on a PC using the Linger software developed by Doug Rohde (http://tedlab.mit.edu/ dr/Linger/).

Instructions on the modality of the experiment were given by the researcher and presented on the computer screen. The participants were instructed on the functioning of the moving window display. A line of dashes, separated by blank spaces, would appear on the screen, covering words of a sentence, each dash covering one character of a word. At the first press of the space bar, a word would appear on the screen, replacing the first set of dashes. At a second press of the space bar, a new word would appear and the previous word would be replaced by dashes again. The time required to press the space bar for each word was

[7] In the original English study, the second NP (the direct object in actives/the agent argument within the $b y$-phrase in passives) was preceded by two coordinated adjectives so as to provide a long postverbal region and increase the chance to identify potential spill-over effects in the processing of the verb. This region was followed by two prepositional phrases, which were included to test for spill-over effects in the processing of the by-phrase itself (first PP) and to avoid end of sentence effects (second PP). Both features were kept in the German version to allow proper comparison.

[8] We should point out that while a proportion of comprehension questions in the English experiments in Paolazzi et al. $(2015,2016)$ also targeted thematic role relations, the experiments also contained a number of more general questions targeting other aspects of the sentences. Analysis of the English results did not reveal any effects of type of question on accuracy. 


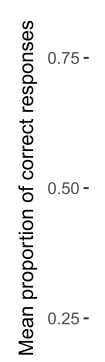

$0.00-$

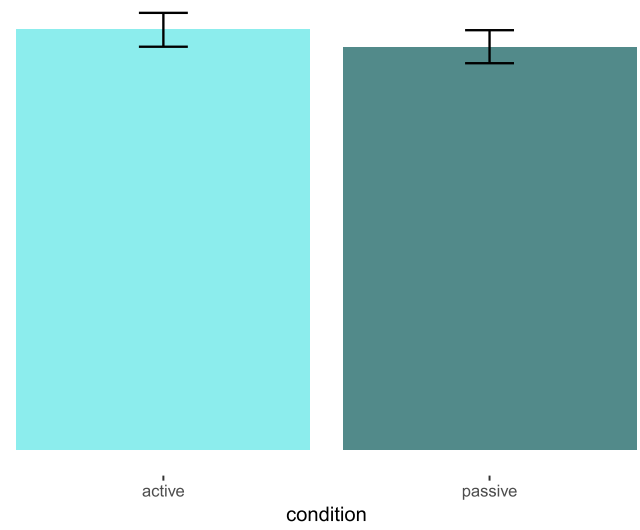

Figure 1

Mean proportion of correct responses per condition with confidence intervals.

recorded by the software. Upon the final key press, a comprehension question appeared to which participants responded by key presses ('F' for YES, ' $\mathrm{J}$ ' for $\mathrm{NO}$ ). Each sentence was followed by a comprehension question. Each participant was first familiarized with the experimental method via a series of practice trials, which were excluded from data analysis. All experiments were performed in a soundproof booth at the Linguistics Lab at the University of Stuttgart using a PC desktop computer. A Razer@(Black Widow@2014) gaming keyboard $(1000 \mathrm{~Hz}$ polling rate) was used for accurate timing. The experiment took approximately 20 minutes to complete. Participants were instructed to take breaks only after answering the comprehension question. A mandatory break was planned in the middle of the experiment.

\section{Data analysis}

\section{Comprehension data analysis and results}

All participants scored above $70 \%$ accurate on comprehension questions. Comprehension question accuracy was analyzed with a mixed effects model in $\mathrm{R}$ with a binomial distribution. Voice was the Fixed Effect and Item and Participant were Random Effects. Both random intercepts and slopes were included. The analysis did not show any significant difference in accuracy across condition. The percentage of correct responses for actives was $80.6 \%$, and it was $77.3 \%$ for passives. This effect was not significant $(p$-value $=.12$ ). 


\section{Response times}

Statistics were performed by using mixed effect regression models as implemented in the R-package lme4 (Bates et al. 2014). Response times were analyzed in a linear mixed effects model with Voice as Fixed Effect and Item and Participant as Random Effects. Both random intercepts and slopes were included. P-values were determined through treating the t-value as a $\mathrm{z}$-statistic (Barr et al. 2013). The effect of Voice was not significant $(p$-value $=.11)$.

\section{Reading time analysis}

Reading times longer than $2500 \mathrm{~ms}$ and shorter than $100 \mathrm{~ms}$ were eliminated from the analysis. Residual RTs (RRTs) were calculated on the remaining log transformed RTs for each subject from the difference between a word logRT and its predicted $\log$ RT based on a model that included number of characters (considering both experimental and filler items) as a Fixed Effect and Participant Random Effects (intercept only). This is a standard procedure for self-paced reading data and works to eliminate the confounding effects of individual reading speed and character length per word (Ferreira \& Clifton 1986). Residual reading times that deviated from the mean by more than 2.5 standard deviations (per participant and region) were automatically eliminated from the analysis at this point using Kevin Tang's Linger Toolkit (Tang 2014; Linger Toolkit. http://tangkevin.github.io/Tools.html). Residual reading times were analyzed with a linear mixed effects model in R with Voice as a Fixed Effect and Item and Participant as Random Effects. Both random intercepts and slopes were included. ${ }^{9}$ There were three regions of interest: (1) the second DP (embedded within the by-phrase in the passive condition), (2) the participle and (3) the postverbal region.

\section{Reading time results and intermediate discussion}

As in the English study reported in Paolazzi et al. (2015), we found that passives were read numerically faster than actives at multiple regions (see Figure 2). Reading times were significantly faster for passives two regions downstream from the beginning of the by-phrase (i.e. at the first prenominal adjective attractive, $27 \mathrm{~ms}$ faster on average in passives, $p$-value $=.027$ ), and approached significance at the conjunction, $14 \mathrm{~ms}$ faster for passives, $(p$-value $=.08)$. Taken together, these

[9] For comparison, we also calculated and analyzed RRTs based on a more complex model, including the restricted cubic spline of word position in the sentence and item position in the stimulus list, in Hofmeister (2011). As the results did not change across the two models (or when only log transformed RTs were considered), we will report the results of the simplest model. Notice also that the plot in Figure 2 appears to show an effect of Voice at the auxiliary. Contrary to the other effects, however, this was only observed when looking at RRTs and not at raw RTs (RTs are $7 \mathrm{~ms}$ shorter for actives) or $\operatorname{logRTs}$. This seems to suggest that the purported difference is an artifact of the residualization process. Importantly, the main effects reported here were independent from residualization. 


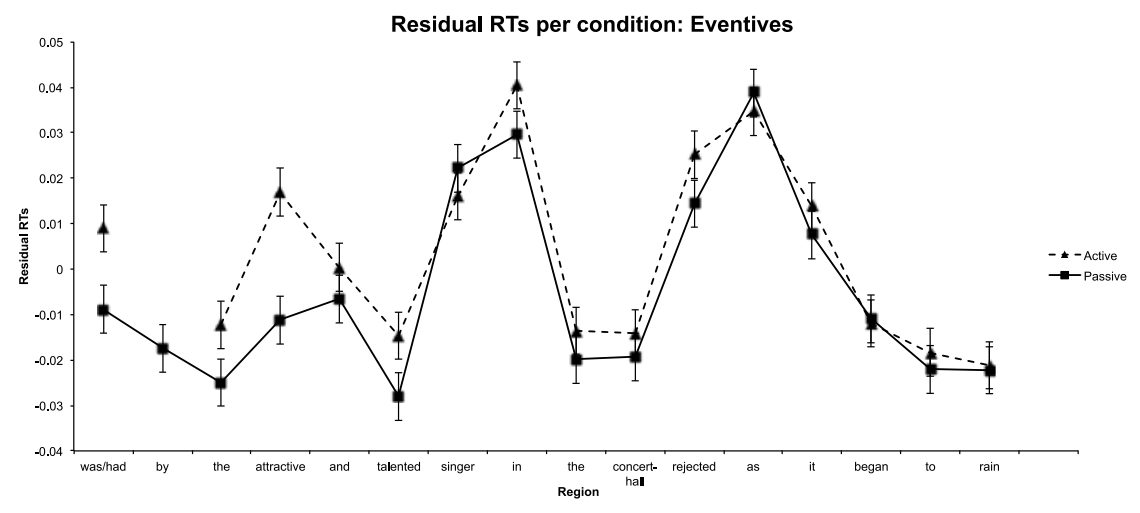

Figure 2

Mean residual RTs per region.

results support the idea that the higher number of morphological cues in passives (i.e. presence of von 'by') reduces surprisal associated with the following DP and locally reduces syntactic processing complexity.

Contrary to what was observed in English, where faster RTs at the verb in passives are better understood in a surprisal framework as a consequence of the presence of an auxiliary immediately preceding the verb (hence the lack of difference between passives and progressives), there was no effect of Voice at the verb in the unambiguously verbal passive in German ( $p$-value $=.37$ ). We have suggested above that the likelihood of a verb following the second DP is higher with by-phrases than with accusative objects, which would lead to the prediction of faster RTs at the verb in passives than actives. ${ }^{10}$ It is possible that the presence of both a locative PP and a temporal modifier between the second DP and the verb might reduce the chance to observe this effect, as they increase expectation of a verb also in the active condition. This cross-linguistic difference was also predicted as both actives and passives were introduced by auxiliaries in our experiment (remember that the presence of the auxiliary was already shown to be the main factor in determining RTs at the verb in Paolazzi et al.'s results). Voice did not affect RTs at any other region.

Overall, therefore, the results add to the picture sketched in Paolazzi et al. (2015): passives of eventive predicates are not harder to parse than corresponding actives, and faster RTs are observed in the presence of richer morphological cues and are best explained as a consequence of surprisal. Let us then turn to Experiment 2, in which we investigated verbal passivization of stative predicates.

[10] We will come back to these data in the comparison between Experiments 1 and 2 below. The combined results show a main effect of syntax at the verb, across both experiments, suggesting a potential issue of power. 


\section{EXPERIMENT 2}

As discussed in Section 1, passives of states in English can, at least locally, be parsed as adjectival passives. Paolazzi et al. (2016) claimed that the complexity effect observed with passives of stative predicates is due to this ambiguity: complexity arises from a conflict between an initial preference for the adjectival interpretation and the difficulty of integrating a referential by-phrase within this parse.

Experiment 2 tests this account by looking at the processing of verbal passives of stative predicates in German. As already noted, since all passives with the auxiliary werden 'become' can only receive a verbal interpretation, regardless of whether the input is eventive or stative, this language offers a perfect testing ground for the previous account. In particular, our prediction is that given the lack of adjectival/verbal ambiguity, verbal passives of states should also not be harder than actives in German, just like the results we had for verbal passives of events reported in Experiment 1. One can notice another difference from English: German is verb-final; the by-phrase precedes the verb, so that any measure of complexity would therefore be expected to show up at the verb or as spill-over in the regions following it.

We therefore expect to replicate an RT advantage for passives over actives at the region of the second DP/by-phrase observed in Experiment 1 (also observed for English). Because of the lack of adjectival/verbal ambiguity and of the availability of a stative interpretation for the German verbal passives, we should not observe any inversion of the effect at the verb or at the following regions. Contrary to English, we should also not expect an advantage for actives over passives in our offline measure (comprehension accuracy).

\section{Participants}

Thirty-four German native speakers, all students from the University of Stuttgart, gave their informed consent to participate in the study and received either course credits or monetary compensation for their participation.

\section{Materials and design}

We constructed 24 minimal pairs of active/passive sentences following the format in (21). ${ }^{11}$ Translation of the stimuli from the experiment on statives in Paolazzi et al. (2016) proved more difficult, so new stimuli were constructed that obeyed the same format as the original ones. To ensure comparability with the original

[11] Note that this experiment differs from the previous one in that we avoided the long PP in between the $b y$-phrase and the verb. This additional region was initially introduced to test for potential spill-over effects following the $b y$-phrase and before the verb. No such effects were observed, however. Furthermore, as the two sets of stimuli do not differ until the verb, i.e. after this region, we wanted to avoid making the experiment unnecessarily longer. 
study and uniformity across the predicates used, we used standard tests of stativity. For consistency and comparability with the English experiment, we used almost exclusively subject experiencer predicates. There is broad consensus in the literature that these predicates are clearly stative (see, e.g., Landau 2010, Fábregas \& Marín 2015 and literature cited therein). Additionally, we used standard stativity tests for German (see Maienborn 2003, 2005), such as anaphoric reference with geschehen 'happen', incompatibility with adverbs of intent, incompatibility with locative modifiers, incompatibility with in-adverbials/compatibility with foradverbials, etc. Furthermore, since German is verb-final, we added a subordinate (causal or concessive) clause to create an additional region after the verb to test for spill-over effects. All stimulus sentences were normed for plausibility of thematic role assignment in an online questionnaire. The structure of each stimulus sentence was kept constant, with a subject DP followed by the auxiliary (become versus have), the by preposition (in passives only), the second DP, which contained two adjectives preceding the head noun, followed by the participle and finally a causal or concessive clause (21). A full list of the stimuli is available in Appendix B. The experimental procedure was kept identical to the one of Experiment 1.

\section{(21) EXAMPle SENTENCES From EXPERIMENT 2:}

(a) Der eigenwillige Schriftsteller wurde von seinem the.NOM headstrong.NOM writer.NOM became by his seltsamen und wortkargen Kollegen respektiert, obwohl er ihn strange and taciturn colleague respected although he him nicht mochte.

not liked

'The headstrong writer was respected by his strange and taciturn colleague, even though he did not like him.'

(b) Der eigenwillige Schriftsteller hat seinen seltsamen und the.NOM headstrong.NOM writer.NOM has his strange and wortkargen Kollegen respektiert, obwohl er ihn nicht mochte. taciturn colleague respected although he him not liked 'The headstrong writer had respected his strange and taciturn colleague, even though he did not like him.'

Let us then turn to the data analysis and the results.

\section{Data analysis and results}

Data analysis was conducted exactly as in the previous experiment.

\section{Accuracy}

Due to low accuracy results on fillers (lower than 70\% overall), two participants were excluded from the final analysis. Hence, data from 32 participants were 
analyzed. As shown in Figure 3, unambiguous verbal passives of stative verbs are understood just as well as their active counterparts (actives $85.9 \%$ correct, passives $83.5 \%$ correct, $p$-value $=0.48$ ). This indirectly supports the idea that the main factor explaining lower performance with stative passives in English relates to the adjectival/verbal ambiguity, which is absent in German.

Mean accuracy per condition Statives

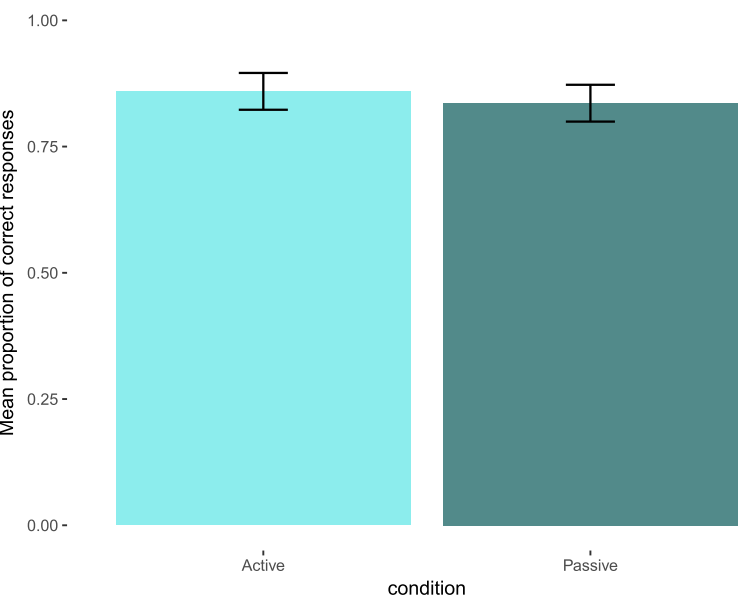

Figure 3

Mean proportion of correct responses per condition with confidence intervals.

\section{Response times}

Response times did not differ across condition $(t=-1.50, p$-value $=.132)$.

\section{Reading times}

As in Experiment 1, we found an effect of Voice at multiple regions, with faster RTs for passives than actives, as can very clearly be seen in Figure 4.

The effect was significant at two regions within the second DP (i.e. the byphrase $)$, namely at the determiner $(p$-value $=.0002)$, first adjective $(p$-value $=$ $.011)$, conjunction $(p$-value $=.021)$ and crucially at the verb $(p$-value $=.003)$. No other effect was significant.

Taken together with the offline results, the RT effects show that, contrary to English passives with stative inputs, which are potentially ambiguous between a verbal and an adjectival parse, German unambiguously verbal passives are not harder to process than actives. 


\section{Residual RTs per Condition: Statives}

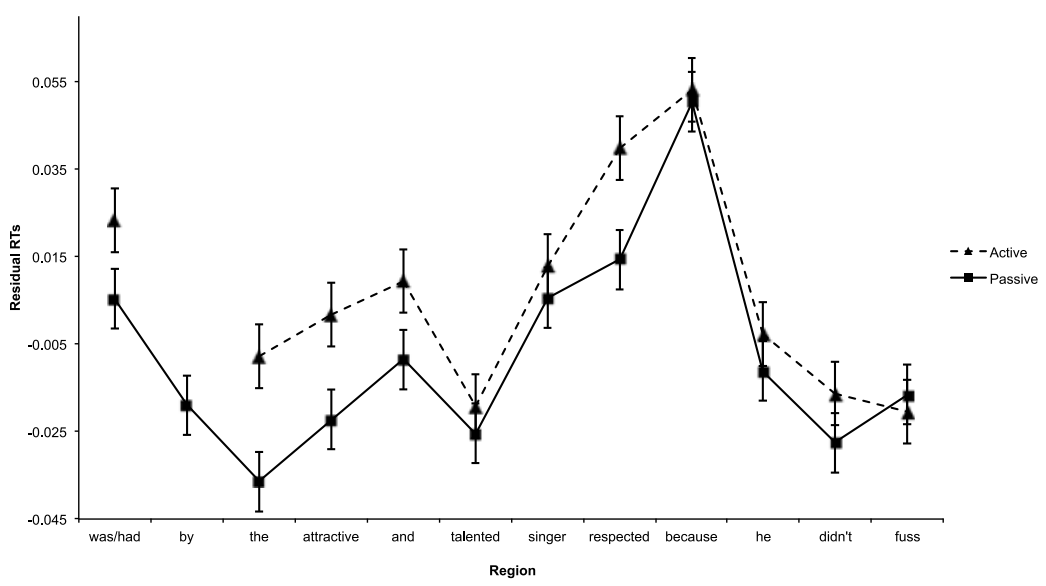

Figure 4

Mean residual RT per region for Experiment 2.

\begin{tabular}{lcclc}
\hline Region & Coefficient & SE & $z$-value & $p$-value \\
\hline Determiner DP2 & 0.025 & 0.006 & 3.718 & 0.0002 \\
First adjective DP2 & 0.022 & 0.008 & 2.53 & 0.011 \\
Conjunction DP2 & 0.014 & 0.006 & 2.302 & 0.021 \\
Verb & 0.03 & 0.01 & 2.9 & 0.003 \\
\hline
\end{tabular}

Table 1

Effect of voice contrast on residual RT at different regions.

\section{Comparison}

An additional analysis was conducted to establish whether there was any difference in RTs and accuracy across Experiments 1 and 2.

\section{Reading times}

The results of the interaction analysis of the RTs at the verb are summarized in Table 2.

Analysis of the RT results at the verb showed no interaction between Voice and $V($ erb $)$-type $(p$-value $=0.403)$ and no main effect of V-type $(p$-value $=0.879)$. Only an overall effect of Voice was observed $(p$-value $=.005)$, with verbs read faster in passives than actives across both statives and eventives. 


\begin{tabular}{llccrr}
\hline Region & Contrast & Coefficient & SE & $z$-value & $p$-value \\
\hline \multirow{2}{*}{ Verb } & Voice & -0.02 & 0.007 & -2.753 & 0.005 \\
& V-type & 0.001 & 0.011 & 0.151 & 0.879 \\
& Voice*V-type & -0.011 & 0.0141 & -0.836 & 0.403 \\
\hline
\end{tabular}

Table 2

Analysis of interaction of V-type and Voice on residual RT at the verb.

Analysis of the pre-verbal region was irrelevant, as the relevant difference between the two experiments was $V$-type. Analysis of postverbal regions did not reveal any significant interaction or main effects.

\section{Accuracy}

As shown in Table 3, a clear lack of interaction of V-type and Voice also emerges from the analysis of the accuracy results. We do, however, observe a marginal effect of Voice on accuracy when the two data sets are combined ( $p$-value $=.09$ ).

Summarizing, there was no interaction between V-type and Voice on either RT or accuracy. The combined analysis also revealed a significant effect of Voice on $\mathrm{RT}$ at the verb, across verb type. A significant effect was previously only observed in the stative experiment, with RTs only numerically faster in passives than actives in the eventive condition. This was likely due to an issue of power. Finally, we observe an overall better accuracy, across both actives and passives, with stative than eventive predicates. ${ }^{12}$

\begin{tabular}{lrrrr}
\hline Contrast & Coefficient & SE & $z$-value & $p$-value \\
\hline Voice & -0.207 & 0.125 & -1.651 & 0.09 \\
V-type & 0.485 & 0.179 & 2.703 & 0.006 \\
Voice*V-type & 0.022 & 0.251 & 0.088 & 0.93 \\
\hline
\end{tabular}

Table 3

Analysis of accuracy across Experiments 1 and 2.

\section{DISCUSSION AND CONCLUSIONS}

Not many experiments have investigated the processing of passive sentences in unimpaired adults, and the few existing studies were conducted mostly in

[12] This is reminiscent of the results in Gennari \& Poeppel (2003), which suggested that stative predicates might be easier to process than eventive ones. Notice, however, that Gennari \& Poeppel (2003) reported an advantage for statives on RTs, while here we observe a similar advantage on accuracy only. 
English and typically measured either offline comprehension or RTs, but not both. A fragmented picture emerges from these studies, showing that passives lead to worse performance in comprehension (Ferreira 2003), but faster RTs in reading (Carrithers 1989, Rohde 2003, Traxler et al. 2014). As discussed in the introduction, following Paolazzi et al. $(2015,2016)$, it is hard to evaluate the role of Voice alternation itself in determining previous results as, in English, these are potentially confounded by three factors: (1) variable degree of morphological richness across voice, which likely influences RTs; (2) ubiquitous presence of adjectival/verbal passive ambiguity in English; (3) the use of a mixed bag of verbs, which is problematic in the light of (2) since event structure interacts with this ambiguity in English.

Paolazzi et al. $(2015,2016)$ argued that a clearer picture emerges when these factors are controlled for. The previously observed passive advantage in RTs can be largely explained away as an effect of surprisal, due to richer morphological information in passives than actives. In English, the processing of passivization interacts with predicate semantics in predictable ways: passives of eventive verbs are not harder to understand than corresponding actives. Complexity effects emerge when stative verbs are passivized, as these are initially more likely to receive an adjectival interpretation, which successively requires reanalysis and coercion into an inchoative state.

These arguments make a strong case for in-depth, targeted cross-linguistic investigation on the interplay of each of these complex factors in determining complexity of passivization. Cross-linguistic research, we have claimed, should target languages that modulate each of these factors independently from one another. In other words, it is not enough to simply test the processing of passives across languages, we should target specific languages (e.g. German, Italian) on the basis of how each of these factors can be isolated from the others. Here, we targeted German, which, contrary to English, disambiguates verbal passives early on in the sentence (through the auxiliary werden 'become' followed by the preposition von 'by'). This allowed us to control for the adjectival/verbal passive ambiguity. Interestingly, English and German verbal passives also differ along another dimension: German verbal passives of stative verbs can still denote states.

We simultaneously tested the online parsing and offline comprehension of passives in two self-paced reading studies, with comprehension questions following each sentence. The first experiment looked at effects of Voice (active-passive) on RT and comprehension of sentences containing eventive predicates (as in Paolazzi et al. 2015). The same contrast was tested in the second experiment, but using only stative verbs (subject experiencer predicates, as in Paolazzi et al. 2016).

The results add to the previous literature in multiple ways. First of all, we observe a genuine asymmetry between online and offline results. While we did find a marginal effect of voice in comprehension questions, voice does not appear to significantly affect comprehension. More importantly, and contrary to the predictions of Good Enough Processing and the Agent First Strategy, this result was not associated with longer RTs. As seen in the introduction, Shallow 
Processing states that correct interpretation of passives will only be achieved when Agent First heuristics are replaced by slower/more effortful algorithmic processes. This leads to predict longer RTs in passives. Reading times, however, were faster for passives than actives at multiple regions. This effect, observed across the two experiments, was significant within the second DP and the verb. One should notice that, as standard, RTs of incorrect trials were removed. That is, faster RTs cooccurred with correct comprehension, which excludes a potential speed-accuracy trade-off analysis. Results from the visual world paradigm (Kamide, Scheepers \& Altmann 2003, Knoeferle \& Crocker 2006, Meyer, Mack \& Thompson 2012) paint a somewhat similar picture: (unimpaired) adult speakers are able to rapidly and reliably revise an initial active bias upon hearing semantic or morphosyntactic cues signaling passive voice. ${ }^{13}$

Following Paolazzi et al. (2015, 2016), we argue that the present results support a surprisal-based (e.g. Hale 2001) or expectation-based account (e.g. Levy 2008). Faster RTs within the second DP parallel what was observed for English; both can be taken to reflect lower surprisal for a DP following the by/von preposition.

Faster RTs at the verb were also observed in English, but in that case they could be ascribed to the presence or absence of an auxiliary (with an advantage observed for passives and progressive actives, but not simple past actives). It should be recalled, however, that (to control for word order) an auxiliary was present in both actives and passives in the present experiment. A different explanation for this effect is needed.

We have suggested that, once certain properties of default word order and morphological richness are considered, a surprisal account naturally predicts faster RTs at the verb in German passives. We have previously seen that morphological richness can lead to increased expectation for particular constituent types: presence of the auxiliary led to shorter reading times in passives and progressives in English. In the present experiments, both actives and passives contained an auxiliary; in German, however, the verb is also preceded by the second DP (byphrase/object DP). We argued that prediction of a verb is stronger after a $b y$-phrase than after a simple accusative-marked DP. The additional piece of morphology in passives (by) makes processing of the verb easier because by-phrases are less likely than direct object to be followed by spatial or temporal event modifiers out of the blue (as in the present experiment). We have shown that these orders are non-canonical in passives, in that they require a special intonation/information structure, neither of which is required of actives.

A second crucial result is that, as predicted, there was no interaction between verb type and voice on RT and accuracy. Contrary to what was observed in English by Paolazzi et al. (2016), passives of statives did not elicit more errors in comprehension than passives of eventive predicates. This difference, we claim,

[13] An active bias, intended as an initial prediction for the more frequent active form, is not to be confused with a heuristic. 
follows from a basic grammatical difference between English, which does not morphologically distinguish between adjectival and verbal passives, and German, which unambiguously introduces verbal passives through the werden 'become' auxiliary.

By embedding stative verbs in unambiguously verbal passives in German, we indirectly support the claim that the interaction of the adjectival/verbal ambiguity with event structure is responsible for previously observed complexity effects with English passives. In English, this ambiguity is maintained up until the referential by-phrase, which forces structural reanalysis and possibly coercion of the stative predicate into a consequent state. As no ambiguity is present in German (and furthermore no coercion into an inchoative reading is needed), no complexity effects are expected.

Taken together, our results endorse the call for targeted cross-linguistic research in psycholinguistics more generally, and in particular in the complex domain of voice alternation. The results further support and complete the account proposed by Paolazzi et al. $(2015,2016)$ for the English results: passives are not necessarily harder than actives. In fact, when the adjectival/verbal ambiguity is removed from the picture, as is done in a language in which the passive in question is unambiguously a verbal one, like German, passives are just as easy to parse as actives.

Finally, from an acquisition perspective, these results might be expected as well. As mentioned, the centrality of event structure and the adjectival/verbal ambiguity in passivization was already recognized in the acquisition literature. Borer \& Wexler (1987) suggested that children's asymmetric ability to deal with passives of 'actional' and 'nonactional' passives stems from their inability to derive verbal passives through A-movement of the internal argument. Being unable to derive passives via A-movement, children resort to an adjectival parse when possible. In this perspective, passives of actional verbs are easier because they can more easily receive an adjectival interpretation (as in, e.g., the girl is well-combed).

Gehrke \& Grillo (2009) suggested that the relevant distinction is not based on actionality, but on event structure. (Many) states, in fact, freely participate in adjectival passivization across languages but resist verbal passivization in many languages. Gehrke and Grillo's account, therefore, is radically different from that proposed in Borer and Wexler (and very much in line with the account discussed here): verbal passives of states are hard because they initially license an adjectival interpretation, which then turns out to be incompatible with referential by-phrases. In some languages, furthermore, states need to be coerced into events to successfully participate in verbal passivization, which further adds to their complexity. Predicates describing complex events, on the other hand, readily passivize across languages. This predicts a potential domain of variation in acquisition: passives should be harder to acquire/understand in languages like English, where they are potentially ambiguous until the head of the by-phrase. In languages like German, on the other hand, verbal passives are disambiguated 
early, which might make them less problematic for children to acquire. In a large-scale investigation on the acquisition of passivization across languages, Armon-Lotem et al. (2016) tested children's ability to comprehend passives in 11 typologically different languages. In line with our results, the study found that passives are easier to acquire in languages such as German where they are uniquely marked, unlike what the literature on passive acquisition reports for English. The study, unfortunately, only tested passives of 'actional' verbs. More work is thus needed to properly test the interaction of grammatical differences and event structure in the acquisition of passives.

To complete this picture, in future work, we plan to test the processing of unambiguously verbal passives in Italian. As discussed above, Italian passives display a mixed set of properties. Like English, Italian has ambiguous be-passives to introduce either adjectival or verbal passives and, similarly to German, it can disambiguate for the verbal reading via the auxiliary venire. Importantly, contrary to German werden-passives, Italian venire passives force an inchoative interpretation of stative verbs. This partial overlap with German would allow one to assess whether the main factor distinguishing English from German is the lack of ambiguity or the lack of coercion.

Summarizing, we presented two self-paced reading studies, with comprehension questions following each sentence, testing the processing of unambiguously verbal passives in German. The first experiment contrasted the processing of actives and passives built on eventive predicates, while the second used stative verbs. The main findings of the paper are as follows.

(22) German passives are read faster than actives, similarly to what was previously observed in English (Carrithers 1989; Traxler et al. 2014; Paolazzi et al. 2015, 2016), which supports an expectation-based (e.g. Levy 2008) or surprisal-based account (e.g. Hale 2001).

(23) German passives are just as easy to understand as their active counterparts, which argues against Shallow Processing and Agent First Strategy.

(24) Comprehension accuracy with unambiguous verbal passives in German is independent of the event structure associated with the underlying predicate, contrary to what was observed for English, which suggests an account for the latter based on the adjectival/verbal ambiguity and coercion, as proposed in Paolazzi et al. (2016). ${ }^{14}$

[14] These results relate to theories of passivization. Alexiadou et al. (2015), for example, assumed an identical structural analysis for English and German passives, but our results show that this should be revised. Alexiadou et al. (2015: 134) considered further differences between English and German passives which might support analyses treating the auxiliary werden as the realization of a passive head in German (Pitteroff 2009). 


\section{APPENDIX A}

\section{Items in Experiment 1}

(1) (a) Der Gitarrist wurde von der attraktiven und talentierten Sängerin in der Konzerthalle zurückgewiesen, während es zu regnen begann.

(b) Der Gitarrist hat die attraktive und talentierte Sängerin in der Konzerthalle zurückgewiesen, während es zu regnen begann.

(2) (a) Der Caterer wurde von dem kreativen und kompetenten Küchenchef in der Küche bezahlt, während das Telefon zu klingeln begann.

(b) Der Caterer hat den kreativen und kompetenten Küchenchef in der Küche bezahlt, während das Telefon zu klingeln begann.

(3) (a) Der Auszubildende wurde von dem unbedarften und ungeschickten Elektriker in dem Physiklabor verletzt, während Wolken aufkamen.

(b) Der Auszubildende hat den unbedarften und ungeschickten Elektriker in dem Physiklabor verletzt, während Wolken aufkamen.

(4) (a) Der Detektiv wurde von der lauten und feindseligen Zeugin vor der Lobby bedrängt, während sich die Tür zu öffnen begann.

(b) Der Detektiv hat die laute und feindselige Zeugin vor der Lobby bedrängt, während sich die Tür zu öffnen begann.

(5) (a) Der Produzent wurde von dem untalentierten und überheblichen Künstler in dieser Woche verklagt, während die Sonne schien.

(b) Der Produzent hat den untalentierten und überheblichen Künstler in dieser Woche verklagt, während die Sonne schien.

(6) (a) Der Küchenchef wurde von dem aggressiven und aufsässigen Kellner in der Restaurantküche erstochen, während die Kunden zu gehen begannen.

(b) Der Küchenchef hat den aggressiven und aufsässigen Kellner in der Restaurantküche erstochen, während die Kunden zu gehen begannen.

(7) (a) Der General wurde von dem täuschenden und feigen Soldat in dem Wald zurückgelassen, während die Feinde den Angriff wieder aufnahmen.

(b) Der General hat den täuschenden und feigen Soldat in dem Wald zurückgelassen, während die Feinde den Angriff wieder aufnahmen.

(8) (a) Der Politiker wurde von der eifersüchtigen und gekränkten Kellnerin auf der Männertoilette verletzt, während die Pressevertreter draußen beschäftigt waren.

(b) Der Politiker hat die eifersüchtige und gekränkte Kellnerin auf der Männertoilette verletzt, während die Pressevertreter draußen beschäftigt waren.

(9) (a) Der Anwalt wurde von dem nervösen und unehrlichen Richter in der überfüllten Cocktailbar gegenüber des Amtsgerichts bestochen, während die Angeklagten auf den Beginn der Verhandlung warteten. 
(b) Der Anwalt hat den nervösen und unehrlichen Richter in der überfüllten Cocktailbar gegenüber des Amtsgerichts bestochen, während die Angeklagten auf den Beginn der Verhandlung warteten.

(10) (a) Die Studentin wurde von dem frauenfeindlichen und rassistischen Professor in diesem Spracheninstitut bedrängt, während die Party im Obergeschoss anfing.

(b) Die Studentin hat den frauenfeindlichen und rassistischen Professor in diesem Spracheninstitut bedrängt, während die Party im Obergeschoss anfing.

(11) (a) Der Verkäufer wurde von der erfahrenen und kompetenten Mitarbeiterin in der Konzernzentrale eingestellt, während die Konferenz ihre Arbeit wieder aufnahm.

(b) Der Verkäufer hat die erfahrene und kompetente Mitarbeiterin in der Konzernzentrale eingestellt, während die Konferenz ihre Arbeit wieder aufnahm.

(12) (a) Der Direktor wurde von der charmanten und charismatischen Schauspielerin im Café zurückgewiesen, während der Mond hell schien.

(b) Der Direktor hat die charmante und charismatische Schauspielerin im Café zurückgewiesen, während der Mond hell schien.

(13) (a) Der Pilot wurde von dem glatzköpfigen und übergewichtigen Flugbegleiter in der Flughafenlounge erstochen, während das Flugzeug lärmend abhob.

(b) Der Pilot hat den glatzköpfigen und übergewichtigen Flugbegleiter in der Flughafenlounge erstochen, während das Flugzeug lärmend abhob.

(14) (a) Der Bildhauer wurde von dem bizarren und temperamentvollen Fotografen in der Kunstgalerie ausgeraubt, während die Menge sich zu versammeln begann.

(b) Der Bildhauer hat den bizarren und temperamentvollen Fotografen in der Kunstgalerie ausgeraubt, während die Menge sich zu versammeln begann.

(15) (a) Der Demonstrant wurde von dem aggressiven und stämmigen Polizisten in der Straße angegriffen, während die Leute laut zu rufen begannen.

(b) Der Demonstrant hat den aggressiven und stämmigen Polizisten in der Straße angegriffen, während die Leute laut zu rufen begannen.

(16) (a) Die Nonne wurde von dem respektierten und weisen Lehrer im blumigen Garten gerettet, während die Glocken zu läuten begannen.

(b) Die Nonne hat den respektierten und weisen Lehrer im blumigen Garten gerettet, während die Glocken zu läuten begannen.

(17) (a) Die Krankenschwester wurde von dem gutaussehenden und angesehenen Arzt in der Personalküche verführt, während die Operation begann. 
(b) Die Krankenschwester hat den gutaussehenden und angesehenen Arzt in der Personalküche verführt, während die Operation begann.

(18) (a) Der Forscher wurde von der leichtsinnigen und mutigen Reporterin im Labor gerettet, während der Tank lautstark explodierte.

(b) Der Forscher hat die leichtsinnige und mutige Reporterin im Labor gerettet, während der Tank lautstark explodierte.

(19) (a) Die Kellnerin wurde von dem faszinierenden und koketten Model im chinesischen Restaurant verführt, während die Vorstellung weiter ging.

(b) Die Kellnerin hat das faszinierende und kokette Model im chinesischen Restaurant verführt, während die Vorstellung weiter ging.

(20) (a) Der Babysitter wurde von dem vertrauenswürdigen und reifen Apotheker in der Apotheke bezahlt, während das Baby weinte.

(b) Der Babysitter hat den vertrauenswürdigen und reifen Apotheker in der Apotheke bezahlt, während das Baby weinte.

(21) (a) Der Fabrikant wurde von dem verärgerten und gekränkten Auftraggeber in der Kanzlei verklagt, während das Faxgerät piepte.

(b) Der Fabrikant hat den verärgerten und gekränkten Auftraggeber in der Kanzlei verklagt, während das Faxgerät piepte.

(22) (a) Der Mechaniker wurde von dem ruppigen und ärgerlichen Fahrzeugelektriker in der Werkstatt gefeuert, als ein neuer Kunde ankam.

(b) Der Mechaniker hat den ruppigen und ärgerlichen Fahrzeugelektriker in der Werkstatt gefeuert, als ein neuer Kunde ankam.

(23) (a) Der Verdächtige wurde von der listigen und einfühlsamen Kriminalbeamtin im dunklen Verhörzimmer beleidigt, während sich der Wachtmeister Notizen machte.

(b) Der Verdächtige hat die listige und einfühlsame Kriminalbeamtin im dunklen Verhörzimmer beleidigt, während sich der Wachtmeister Notizen machte.

(24) (a) Die Verkäuferin wurde von dem nervösen und hysterischen Kunden in dem Einkaufszentrum gestoßen, als viele Menschen das Einkaufszentrum verließen.

(b) Die Verkäuferin hat den nervösen und hysterischen Kunden in dem Einkaufszentrum gestoßen, als viele Menschen das Einkaufszentrum verließen.

(25) (a) Das Kind wurde von dem jungen und dünnen Babysitter im farbenfrohen Kinderzimmer geschlagen, während die Milch zu kochen begann.

(b) Das Kind hat den jungen und dünnen Babysitter im farbenfrohen Kinderzimmer geschlagen, während die Milch zu kochen begann.

(26) (a) Der Soldat wurde von dem gefährlichen und bewaffneten Rebellen in der Kampfzone entführt, während die Hubschrauber zu landen begannen. 
(b) Der Soldat hat den gefährlichen und bewaffneten Rebellen in der Kampfzone entführt, während die Hubschrauber zu landen begannen.

(27) (a) Der Student wurde von dem betagten und verehrten Professor aus der Bibliothek gerettet, während die Feuerwehrleute eintrafen.

(b) Der Student hat den betagten und verehrten Professor aus der Bibliothek gerettet, während die Feuerwehrleute eintrafen.

(28) (a) Die Tänzerin wurde von dem gewaltsamen und ausfälligen Choreografen in der Umkleide geschlagen, während die Musik zu spielen begann.

(b) Die Tänzerin hat den gewaltsamen und ausfälligen Choreografen in der Umkleide geschlagen, während die Musik zu spielen begann.

(29) (a) Der Ermittler wurde von dem glatzköpfigen und unangenehmen Barkeeper in der Kneipe bestochen, während sich ein Publikum versammelte.

(b) Der Ermittler hat den glatzköpfigen und unangenehmen Barkeeper in der Kneipe bestochen, während sich ein Publikum versammelte.

(30) (a) Der Kletterer wurde von dem unklugen und inkompetenten Reiseführer in dem Unterschlupf zurückgelassen, während die Sonne aufzugehen begann.

(b) Der Kletterer hat den unklugen und inkompetenten Reiseführer in dem Unterschlupf zurückgelassen, während die Sonne aufzugehen begann.

\section{APPENDIX B}

\section{Items in Experiment 2}

(1) (a) Der gewählte Kandidat wurde von dem alten und erfahrenen Parteivorsitzenden abgelehnt, was die Partei in eine erneute Krise stürzte.

(b) Der gewählte Kandidat hat den alten und erfahrenen Parteivorsitzenden abgelehnt, was die Partei in eine erneute Krise stürzte.

(2) (a) Der eigenwillige Schriftsteller wurde von seinem seltsamen und wortkargen Kollegen respektiert, obwohl er ihn nicht mochte.

(b) Der eigenwillige Schriftsteller hat seinen seltsamen und wortkargen Kollegen respektiert, obwohl er ihn nicht mochte.

(3) (a) Der umtriebige Bürgermeister wurde von seinen kritischen und aufgebrachten Mitbürgern geachtet, da in einer Demokratie alle zusammenarbeiten müssen.

(b) Der umtriebige Bürgermeister hat seine kritischen und aufgebrachten Mitbürger geachtet, da in einer Demokratie alle zusammenarbeiten müssen.

(4) (a) Der erfahrene Abteilungsleiter wurde von seinen jungen und alten Kollegen geschätzt, was das Arbeiten für alle angenehmer machte. 
(b) Der erfahrene Abteilungsleiter hat seine jungen und alten Kollegen geschätzt, was das Arbeiten für alle angenehmer machte.

(5) (a) Der kleine Junge wurde von dem gleichaltrigen und netten Nachbarsjungen bewundert, ohne dass dieser das jedoch bemerkte.

(b) Der kleine Junge hat den gleichaltrigen und netten Nachbarsjungen bewundert, ohne dass dieser das jedoch bemerkte.

(6) (a) Der kluge Student wurde von dem erfahrenen und langgedienten Dozenten beneidet, da dieser so selbstsicher und kompetent vor der Gruppe auftrat.

(b) Der kluge Student hat den erfahrenen und langgedienten Dozenten beneidet, da dieser so selbstsicher und kompetent vor der Gruppe auftrat.

(7) (a) Der erfahrene Coach wurde von seinen verwöhnten und verweichlichten Spielern gehasst, solange er den Verein trainierte.

(b) Der erfahrene Coach hat seine verwöhnten und verweichlichten Spieler gehasst, solange er den Verein trainierte.

(8) (a) Der strenge Lehrer wurde von seinen motivierten und fleißigen Schülern geliebt, da alle im Unterricht große Lernfortschritte erzielen konnten.

(b) Der strenge Lehrer hat seine motivierten und fleißigen Schüler geliebt, da alle im Unterricht große Lernfortschritte erzielen konnten.

(9) (a) Der engagierte Mitarbeiter wurde von seinen alten und neuen Kollegen wertgeschätzt, was auch dem Chef nicht verborgen blieb.

(b) Der engagierte Mitarbeiter hat seine alten und neuen Kollegen wertgeschätzt, was auch dem Chef nicht verborgen blieb.

(10) (a) Die fürsorgliche Oma wurde von ihrer netten und besorgten Familie gebraucht, weil in solch schlimmen Situationen nur Zusammenhalt und Liebe helfen.

(b) Die fürsorgliche Oma hat ihre nette und besorgte Familie gebraucht, weil in solch schlimmen Situationen nur Zusammenhalt und Liebe helfen.

(11) (a) Der langjährige Oppositionsführer wurde von dem pflichtbewussten und fleißigen Regierungschef geachtet, da sie in den wichtigen Fragen trotz unterschiedlicher Parteizugehörigkeit gut zusammenarbeiten konnten.

(b) Der langjährige Oppositionsführer hat den pflichtbewussten und fleißigen Regierungschef geachtet, da sie in den wichtigen Fragen trotz unterschiedlicher Parteizugehörigkeit gut zusammenarbeiten konnten.

(12) (a) Die attraktive Frau wurde von ihrem jungen und hübschen Liebhaber verschmäht, was niemand verstehen konnte.

(b) Die attraktive Frau hat ihren jungen und hübschen Liebhaber verschmäht, was niemand verstehen konnte. 
(13) (a) Dem erfahrenen Manager wurde von den alteingessenen und einflussreichen Aktionären vertraut, was sich letztlich als schwerer Fehler erweisen sollte.

(b) Der erfahrene Manager hat den alteingessenen und einflussreichen Aktionären vertraut, was sich letztlich als schwerer Fehler erweisen sollte.

(14) (a) Dem hinterlistigen Gitarristen wurde von seinem aufbrausenden und unberechenbaren Bandkollegen vertraut, weil sie sich schon lange kannten.

(b) Der hinterlistige Gitarrist hat seinem aufbrausenden und unberechenbaren Bandkollegen vertraut, weil sie sich schon lange kannten.

(15) (a) Den neuankommenden Flüchtlingen wurde von den ängstlichen und ablehnenden Anwohnern misstraut, was die Situation für alle sehr schwierig machte.

(b) Die neuankommenden Flüchtlinge haben den ängstlichen und ablehnenden Anwohnern misstraut, was die Situation für alle sehr schwierig machte.

(16) (a) Der erwachsene Sohn wurde von seiner einfühlsamen und fürsorglichen Mutter bemitleidet, was in dieser schlimmen Situation wenigstens etwas Trost spendete.

(b) Der erwachsene Sohn hat seine einfühlsame und fürsorgliche Mutter bemitleidet, was in dieser schlimmen Situation wenigstens etwas Trost spendete.

(17) (a) Der aufbrausende Chef wurde von dem ehrgeizigen und eigenwilligen Mitarbeiter gefürchtet, was sich deutlich negativ auf das Betriebsklima auswirkte.

(b) Der aufbrausende Chef hat den ehrgeizigen und eigenwilligen Mitarbeiter gefürchtet, was sich deutlich negativ auf das Betriebsklima auswirkte.

(18) (a) Der junge Oberarzt wurde von seinen älteren und erfahreneren Kollegen vergöttert, was jedoch niemals offen geäußert wurde.

(b) Der junge Oberarzt hat seine älteren und erfahreneren Kollegen vergöttert, was jedoch niemals offen geäußert wurde.

(19) (a) Der große Künstler wurde von dem alten und weisen Lehrer verehrt, was dieser sich jedoch niemals vorstellen konnte.

(b) Der große Künstler hat den alten und weisen Lehrer verehrt, was dieser sich jedoch niemals vorstellen konnte.

(20) (a) Der aufbrausende Küchenchef wurde von dem vorlauten und aufsässigen Kellner verachtet, was ein ums andere Mal zu Streit führte.

(b) Der aufbrausende Küchenchef hat den vorlauten und aufsässigen Kellner verachtet, was ein ums andere Mal zu Streit führte.

(21) (a) Der sympathische Junge wurde von seinen alten und neuen Mitschülern gemocht, was kein Wunder war. 
(b) Der sympathische Junge hat seine alten und neuen Mitschüler gemocht, was kein Wunder war.

(22) (a) Die attraktive Frau wurde von vielen alten und jungen Männern begehrt, was nicht wenige Probleme mit sich brachte.

(b) Die attraktive Frau hat viele alte und junge Männer begehrt, was nicht wenige Probleme mit sich brachte.

(23) (a) Der junge Tennisstar wurde von seinem sportlichen und fairen Gegner bedauert, was die Niederlage für diesen jedoch nur noch schlimmer machte.

(b) Der junge Tennisstar hat seinen sportlichen und fairen Gegner bedauert, was die Niederlage für diesen jedoch nur noch schlimmer machte.

(24) (a) Der beteiligten Feuerwehrleute wurde von ihren traurigen und leidenden Angehörigen gedacht, was viele wieder an die schrecklichen Ereignisse erinnerte.

(b) Die beteiligten Feuerwehrleute haben ihrer traurigen und leidenden Angehörigen gedacht, was viele wieder an die schrecklichen Ereignisse erinnerte.

\section{REFERENCES}

Alexiadou, Artemis, Elena Anagnostopoulou \& Florian Schäfer. 2015. External arguments in transitivity alternations: A layering approach, vol. 55. USA: Oxford University Press.

Alexiadou, Artemis, Berit Gehrke \& Florian Schäfer. 2014. The argument structure of adjectival participles revisited. Lingua 149B, 118-138.

Anagnostopoulou, Elena. 2003. Participle and voice. In Artemis Alexiadou, Monika Rathert \& Armin von Stechow (eds.), Perfect explorations, vol. 136. Berlin: Mouton de Gruyter.

Armon-Lotem, Sharon, Ewa Haman, Kristine Jensen de López, Magdalena Smoczynska, Kazuko Yatsushiro, Marcin Szczerbinski, Angeliek van Hout, Ineta Dabašinskienè, Anna Gavarró, Erin Hobbs, Laura Kamandulytè-Merfeldienè, Napoleon Katsos, Sari Kunnari, Chrisa Nitsiou, Lone Sundahl, Olsen Xavier Parramon, Uli Sauerland, Reeli Torn-Leesik \& Heather van der Lely. 2016. A large-scale cross-linguistic investigation of the acquisition of passive. Language Acquisition 23.1, $27-56$.

Barr, Dale J., Roger Levy, Christoph Scheepers \& Harry J. Tily. 2013. Random effects structure for confirmatory hypothesis testing: Keep it maximal. Journal of Memory and Language 68.3, 255-278.

Bates, Douglas, Martin Mächler, Ben Bolker \& Steve Walker. 2014. Fitting linear mixed-effects models using lme4. Preprint, arXiv:1406.5823.

Belletti, Adriana \& Luigi Rizzi. 1988. Psych verbs and $\theta$-theory. Natural Language \& Linguistic Theory 6, 291-352.

Bever, Thomas G. 1970. The cognitive basis of linguistic structure. In J. R. Hayes (ed.), Cognition and the development of language, 279-362. New York: Wiley.

Bever, Thomas G \& David Poeppel. 2010. Analysis by synthesis: A (re-) emerging program of research for language and vision. Biolinguistics 4.2-3, 174-200.

Borer, Hagit \& Wexler Kenneth. 1987. The maturation of syntax. In Tomas Roeper \& Edwin Williams (eds.), Parameter setting, 123-172. Dordrecht: Reidel.

Bott, Oliver. 2010. The processing of events, vol. 162. Amsterdam: John Benjamins.

Brennan, Jonathan \& Liina Pylkkänen. 2010. Processing psych verbs: Behavioural and meg measures of two different types of semantic complexity. Language and Cognitive Processes 25.6, 777-807.

Bruening, Benjamin. 2014. Word formation is syntactic: Adjectival passives in English. Natural Language and Linguistic Theory 32.2, 363-422.

Carrithers, Caroline. 1989. Syntactic complexity does not necessarily make sentences harder to understand. Journal of Psycholinguistic Research 18.1, 75-88. 
Christianson, Kiel, Andrew Hollingworth, John F. Halliwell \& Fernanda Ferreira. 2001. Thematic roles assigned along the garden path linger. Cognitive Psychology 42.4, 368-407.

Collins, Chris. 2005. A Smuggling approach to the passive in English. Linguistic Inquiry 36.2, 289-297.

Crawford, Jean. 2012. Developmental perspectives on the acquisition of the passive: $\mathrm{Ph} . \mathrm{D}$. dissertation, University of Connecticut, Storrs, CT.

de Swart, Henriëtte. 1998. Aspect shift and coercion. Natural Language and Linguistic Theory 16.2, 347-385.

Eroms, Hans-Werner. 1992. Das deutsche Passiv in historischer Sicht. In Ludger Hoffmann (ed.), Deutsche syntax: Ansichten und Aussichten, 225-249. Berlin and New York: Walter de Gruyter.

Estrela, Antónia Pimentel. 2014. A aquisição da estrutura passiva em português europeu: Faculdade de Ciências Sociais e Humanas, Ph.D. dissertation, Universidade Nova de Lisboa.

Fábregas, Antonio \& Rafael Marín. 2015. Deriving individual-level and stage-level psych verbs in Spanish. The Linguistic Review 32.2, 227-275.

Ferreira, Fernanda. 2003. The misinterpretation of noncanonical sentences. Cognitive Psychology 47, 164-203.

Ferreira, Fernanda \& Kiel Christianson. 2016. Is now-or-never language processing good enough? Behavioral and Brain Sciences 39.

Ferreira, Fernanda \& Charles J. Clifton. 1986. The independence of syntactic processing. Journal of Memory and Language 25.3, 348-368.

Ferreira, Fernanda \& Nikole D Patson. 2007. The 'good enough' approach to language comprehension. Language and Linguistics Compass 1.1-2, 71-83.

Fox, Danny \& Yosef Grodzinsky. 1998. Childrens passive: A view from the by-phrase. Linguistic Inquiry 29.2, 311-332.

Gehrke, Berit. 2015. Adjectival participles, event kind modification and pseudo-incorporation. Natural Language and Linguistic Theory 33.3, 897-938.

Gehrke, Berit \& Nino Grillo. 2007. Aspects on passives. In Sylvia Blaho, Erik Schoorlemmer \& Luis Vicente (eds.), Proceedings of ConSOLE XIV, 121-141, available at http://www.sole.leidenuniv.nl/.

Gehrke, Berit \& Nino Grillo. 2008. How to become passive. In Kleanthes K. Grohmann (ed.), Explorations of phase theory: Features, arguments, and interpretation at the interfaces interface explorations, 231-268. Berlin: de Gruyter.

Gehrke, Berit \& Nino Grillo. 2009. Event structure and the acquisition of passives. Paper presented at VII GLOW in Asia, Hyderabad.

Gennari, Silvia \& David Poeppel. 2003. Processing correlates of lexical semantic complexity. Cognition 89.1, B27-B41.

Gibson, Edward. 1998. Linguistic complexity: Locality of syntactic dependencies. Cognition 68, 1-76.

Grillo, Nino. 2008. Generalized Minimality: Syntactic underspecification in Brocas Aphasia: Ph.D. dissertation, Utrecht University.

Grodzinsky, Yosef. 1990. Theoretical perspectives on language deficit. Cambridge, MA: MIT Press.

Grodzinsky, Yosef. 1995. Trace deletion, -roles, and cognitive strategies. Brain and Language 51, 469-497.

Grodzinsky, Yosef. 2000. The neurology of syntax: Language use without Brocas area. Behavioral and Brain Sciences 23, 1-71.

Hale, John T. 2001. A probabilistic Early parser as a psycholinguistic model. In Proceedings of the 2nd North American Chapter of the Association for Computational Linguistics on Language Technologies, 1-8. Association for Computational Linguistics.

Hofmeister, Philip. 2011. Representational complexity and memory retrieval in language comprehension. Language and Cognitive Processes 26.3, 376-405.

Horgan, Dianne D. 1978. The development of full passives. Journal of Child Language 5, 65-80.

Jaeger, Florian T., Evelyn Fedorenko, Philip Hofmeister \& Edward Gibson. 2008. Expectation-based syntactic processing: Anti-locality effects outside of head-final languages. Paper presented at the 21 st Annual CUNY Sentence Processing Conference. NC: University of North Carolina-Chapel Hill.

Just, Marcel A., Patricia A. Carpenter \& Jaqueline D. Woolley. 1982. Paradigms and processes in reading comprehension. Journal of Experimental Psychology 111, 228-238.

Kamide, Yuki, Christoph Scheepers \& Gerry TM Altmann. 2003. Integration of syntactic and semantic information in predictive processing: Cross-linguistic evidence from German and English. Journal of Psycholinguistic Research 32.1, 37-55.

Karimi, Hossein \& Fernanda Ferreira. 2016. Good-enough linguistic representations and online cognitive equilibrium in language processing. The Quarterly Journal of Experimental Psychology $69.5,1013-1040$. 
Knoeferle, Pia \& Matthew W. Crocker. 2006. The coordinated interplay of scene, utterance, and world knowledge: Evidence from eye tracking. Cognitive Science 30.3, 481-529.

Konieczny, L. 2000. Locality and parsing complexity. Journal of Psycholinguistic Research 29.6, $627-645$.

Kratzer, Angelika. 2000. Building statives. In Lisa J. Conathan (ed.), Proceedings of the 26th annual meeting of the Berkeley Linguistics Society, 385-399. Berkeley: Berkely Linguistics Society.

Landau, Idan. 2010. The locative syntax of experiencers LI Monograph, vol. 53. Cambridge, MA: MIT Press.

Lau, Ellen, Clare Stroud, Silke Plesch \& Colin Phillips. 2006. The role of structural prediction in rapid syntactic analysis. Brain and Language 98.1, 74-88.

Levy, Roger. 2008. Expectation-based syntactic comprehension. Cognition 106, 1126-1177.

Levy, Roger, Evelina Fedorenko, Mara Breen \& Edward Gibson. 2012. The processing of extraposed structures in English. Cognition 122.1, 12-36.

Maienborn, Claudia. 2003. Die logische Form von Kopula-Sätzen. Walter de Gruyter GmbH \& Co KG.

Maienborn, Claudia. 2005. On the limits of the Davidsonian approach: The case of copula sentences. Theoretical Linguistics 31.3, 275-316.

Maienborn, Claudia. 2007. Das Zustandspassiv: Grammatische Einordnung - Bildungsbeschränkung - Interpretationsspielraum. Zeitschrift für germanistische Linguistik 35, 83-144.

Maratsos, Michael P., Fox Danny, Judith E. Becker \& Mary A. Chalkley. 1985. Semantic restrictions on children passives. Cognition 19, 167-191.

McElree, Brian, Matthew J. Traxler, Martin J. Pickering, Rachel E. Seely \& Ray Jackendoff. 2001. Reading time evidence for enriched composition. Cognition 78.1, B17-B25.

McIntyre, Andrew. 2013. Adjectival passives and adjectival participles in English. In Artemis Alexiadou \& Florian Schäfer (eds.), Non-canonical passives, 21-42. John Benjamins.

Meyer, Aaron M., Jennifer E. Mack \& Cynthia K. Thompson. 2012. Tracking passive sentence comprehension in agrammatic aphasia. Journal of Neurolinguistics 25.1, 31-43.

Moens, Marc \& Mark Steedman. 1988. Temporal ontology and temporal reference 14.2, 15-28.

Myung-Chul, Koo. 1997. Kausativ und passiv im Deutschen. Frankfurt/M: Peter Lang.

Paczynski, Martin, Ray Jackendoff \& Gina Kuperberg. 2014. When events change their nature: The neurocognitive mechanisms underlying aspectual coercion. Journal of Cognitive Neuroscience 26.9, 1905-1917.

Paolazzi, Caterina, Nino Grillo, Artemis Alexiadou \& Andrea Santi. 2015. Evidence against heuristic processing of English passive sentences. AMLaP (Architectures and Mechanisms for Language Processing). University of Malta.

Paolazzi, Caterina, Nino Grillo, Artemis Alexiadou \& Andrea Santi. 2016. Processing English passives: Interaction with event structure, but no evidence for heuristics. CUNY Conference on Human Sentence Processing. University of Florida.

Piñango, Maria M., Aaron Winnick, Rashad Ullah \& Edgar Zurif. 2006. Time-course of semantic composition: The case of aspectual coercion. Journal of psycholinguistic research 35.3, 233-244.

Piñango, Maria M., Edgar Zurif \& Ray Jackendoff. 1999. Real-time processing implications of enriched composition at the syntax-semantics interface. Journal of Psycholinguistic Research 28.4, 395-414.

Pitteroff, Marcel. 2009. The English eventive passive. Zulassungsarbeit: Universität Stuttgart.

Rapp, Irene. 1996. Zustand? Passiv? Überlegungen zum sogenannten Zustandspassiv. Zeitschrift für Sprachwissenschaft 15.2, 231-265.

Rapp, Irene. 1997. Partizipien und semantische Struktur: Zu passivischen Konstruktionen mit dem 3. Status. Tübingen: Stauffenberg.

Rohde, Douglas. 2003. The on-line processing of active and passive structures in English. Presented at the 16th CUNY Conference on Human Sentence Processing, http://tedlab.mit.edu/ dr/Papers/Rohde-Gibson-CUNY2003.pdf.

Snyder, William \& Nina Hyams. 2015. Minimality effects in childrens passives. In Elisa di Domenico, Cornelia Hamman \& Simona Matteini (eds.), Structures, strategies and beyond: Studies in honour of Adriana Belletti (Linguistik Aktuell/Linguistics Today, 223), 343-368. Amsterdam/Philadelphia: John Benjamins.

Staub, Adrian, Charles Clifton \& Lyn Frazier. 2006. Heavy NP shift is the parsers last resort: Evidence from eye movements. Journal of Memory and Language 54.3, 389-406.

Staub, Adrian \& Charles Clifton Jr. 2006. Syntactic prediction in language comprehension: Evidence from either. . . or. Journal of Experimental Psychology: Learning, Memory, and Cognition 32.2, 425 . 
Tang, Kevin. 2014. Linger toolkit. http://tang-kevin.github.io/Tools.html.

Townsend, David J. \& Thomas G. Bever. 2001. Sentence comprehension: The integration of habits and rules, vol. 1950. Cambridge, MA: MIT Press.

Traxler, Matthew J. 2014. Trends in syntactic parsing: Anticipation, Bayesian estimation, and goodenough parsing. Trends in Cognitive Sciences 18.11, 605-611.

Traxler, Matthew J., David P. Corina, Jill P. Morford, Sara Hafer \& Liv J. Hoversten. 2014. Deaf readers response to syntactic complexity: Evidence from self-paced reading. Memory and Cognition 42, 97-111.

Traxler, Matthew J., Martin J. Pickering \& Brian McElree. 2002. Coercion in sentence processing: Evidence from eye-movements and self-paced reading. Journal of Memory and Language 47.4, 530-547.

Vendler, Zeno. 1957. Verbs and times. Philosophical Review 56, 143-160.

Volpato, Francesca, Laura Verin \& Anna Cardinaletti. 2015. The comprehension and production of verbal passives by Italian preschool-age children. Applied Psycholinguistics 37.4, 901-931.

Zifonun, Gisela. 1992. Das Passiv im Deutschen: Agenten, Blockaden und (De-)Gradierungen. In Ludger Hoffmann (ed.), Deutsche Syntax: Ansichten und Aussichten, 250-275. Berlin and New York: Walter de Gruyter.

Zifonun, Gisela, Ludger Hoffmann \& Bruno Strecker. 1997. Grammatik der deutschen Sprache 3. Berlin/New York: Mouton de Gruyter.

Authors' addresses: (Grillo)

Department of Language and Linguistic Science, University of York,

Heslington, York YO10 5DD, UK

nino.grillo@york.ac.uk

(Alexiadou)

Institut für Anglistik und Amerikanistik, Humboldt-Universität zu Berlin \& Leibniz-Center General Linguistics (ZAS), Unter den Linden 6, 10099, Berlin, Germany artemis.alexiadou@hu-berlin.de

(Gehrke)

Institut für Slawistik und Hungarologie, Humboldt-Universität zu Berlin, Unter den Linden 6, 10099, Berlin, Germany

berit.gehrke@hu-berlin.de

(Hirsch)

Institut für Anglistik und Amerikanistik, Humboldt-Universität zu Berlin, Unter den Linden 6, 10099, Berlin, Germany

nils.hirsch@hu-berlin.de

(Paolazzi)

Department of Linguistics, University College London, 2 Wakefield Street, WC1N 1PF, London, UK

caterina.paolazzi.11@ucl.ac.uk

(Santi)

Department of Linguistics, University College London, 2 Wakefield Street, WC1N 1PF, London, UK

a.santi@ucl.ac.uk 